
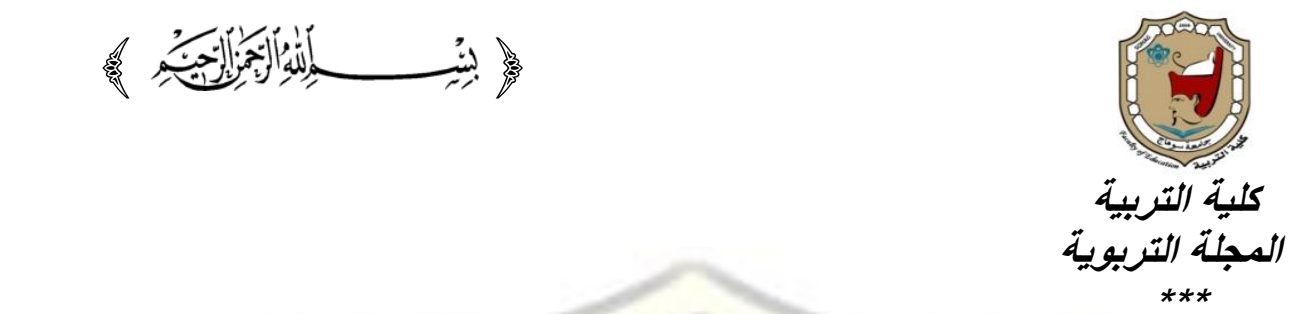

واقع المكانة الاجتماعية للمعلم من وجهة نظر معامي المرحلة الثانوية في همافظة العاصمة بدولة الكويت

\title{
إعداد
}

د. خاللد محمد الفضاله

أستاذ مساعد قسم الأصول والإدارة التربوية كلية التربية الأساسية/ دولة الكويت

المجلة التربوية ـ العدد الثالث والستون ـ يوليو 19 مrم

Print:(ISSN 1687-2649) Online:(ISSN 2536-9091) 
الملخص

هدفت الدراسة الحالية إلى التعرف على واقع المكانة الاجتماعية للمعلم من وجهة نظر معلمي المرحلة الثانوية في محافظة العاصمة بدولة الكويت، والكثف عن الفروق ذات الالالة الإحصائية في وجهات نظر أفراد عينة الدراسة نحو المكانة الاجتماعية للمعلم والتي في تعزى لمتغيرات الجنس والجنسية والتخصص. ولتحقيق أهداف الدراسة، قام الباحث باستخدام المنهج الوصفي التحليلي، ويتطوير استبانة مكونة من ثُلاث مجالات وهي (الجانب الاقتصادي للمعلم، الجانب الاجتماعي للمعلم، جانب الأهمية والتقدير المجتمعي للمعلم)

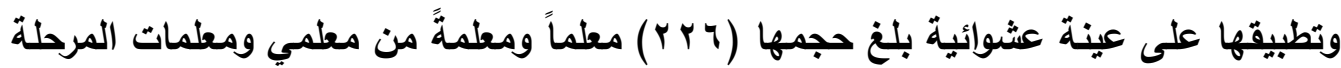
الثانوية في محافظة العاصمة بلولة الكويت. وتوصلت الدراسة إلى عدد من النتائج، ومن أهمها: أن المكانة الاجتماعية للمعلم مرتفعة في الجانب الاجتماعي، ومنخفضة في الجانب الاقتصادي وجانب الأهمية والتقدير المجتمعي، ومتوسطة في الارجة الكلية. كما توصلت الدراسة إلى وجود فروق ذات دلالة إحصائية لاى أفراد عينة الدراسة في المكانة الاجتماعية للمعلم في الجانب الاقتصادي وجانب الأهمية والتقدير المجتمعي والدرجة ككل لصالح الإناث، ووجود فروق ذات دلالة إحصائية في

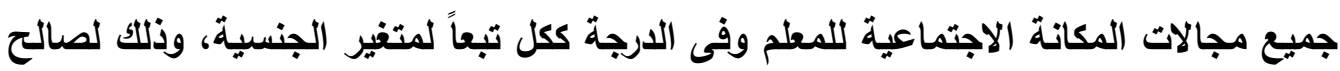
الكويتيين، وعدم وجود فروق ذات دلالة إحصائية في جميع مجالات المكانة الاجتماعية

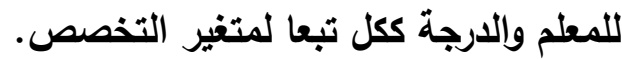
الكلمات المفتاحية: المعلم - المكانة الاجتماعية - المرحلة الثانوية 
واقع المكانة الاجتماعية للمعلم من وجهة نظر معلمي المرحلة الثانوية في محافظة العاصمة بدولة الكويت.

\title{
The Social Status of Teacher from the Point of View of High School Teachers in the Capital Governate of the State of Kuwait
}

\begin{abstract}
The current study aims to identify the reality of the social status of the teacher from the point of view of high school teachers in the capital governate of the state of Kuwait, and to specify the statistically significant differences in sample viewpoints toward the social status of teacher in terms of sex, citizenship, and specialization. To achieve the objectives of the study, the researcher used the descriptive analytical approach through applying a questionnaire on a random sample of (226) high school teachers.

The most important results are that the social status of teacher is high in the social, low in the economic and importance and social appreciation parts, and moderate in the total degree. In addition, the study indicated that there are statistically significant differences from sample view points toward the economic and importance and social appreciation parts and in the total degree according to sex variable in favour of female, and statistically significant differences in all parts and total degree according to citizenship variable in favour of Kuwaiti teachers. Furthermore, there are no statistically significant differences from the sample viewpoint toward all parts and the total degree of the social status of teacher according to specialization variable.
\end{abstract}

Key words: Teacher - Social status - High school 


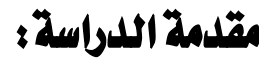

لقد حظي العلم والتعليم والمعلم باهتمام مختلف الأمم والحضارات على مر العصور

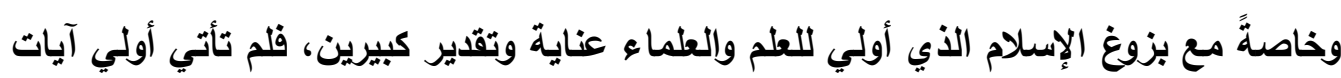

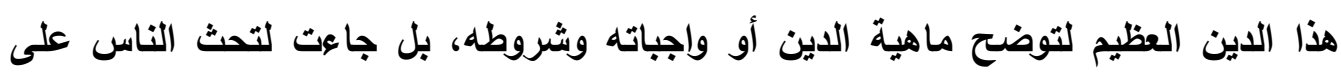

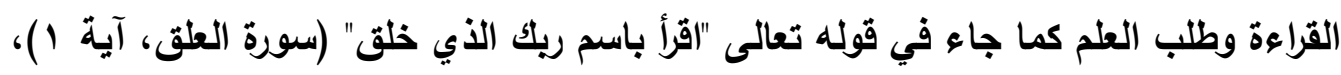

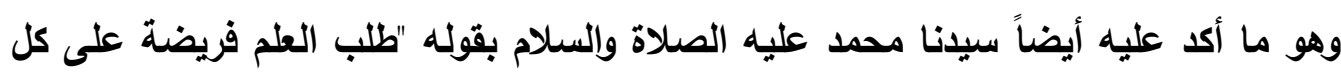

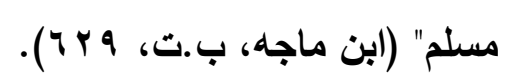

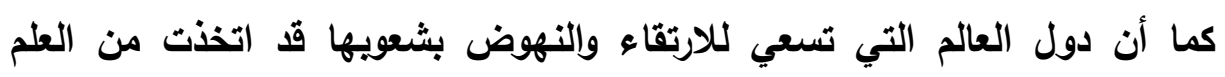

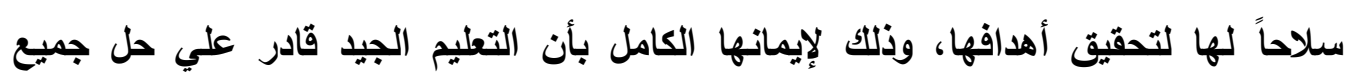

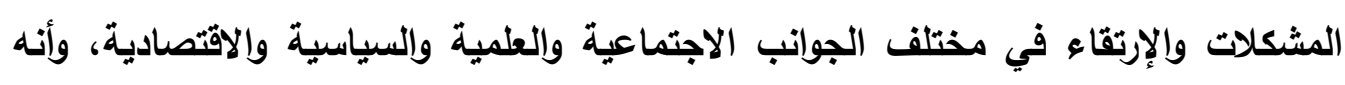

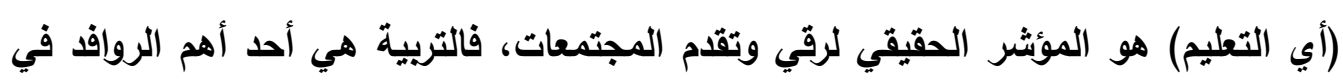

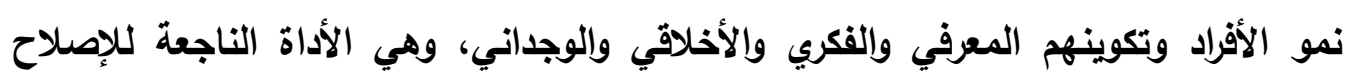
والتغيير والبناء.

وترى السبعاوي أنه يجب النظر للعملية التعليمية باعتبارها "وحدة مترابطة لايمكن

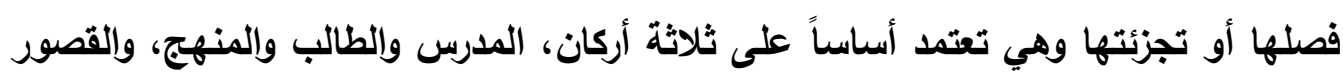

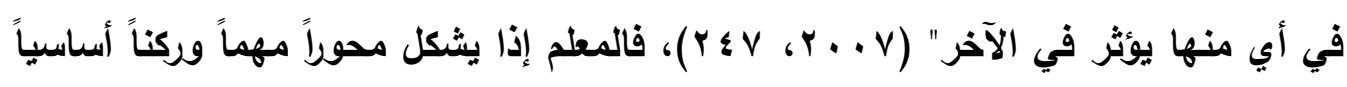

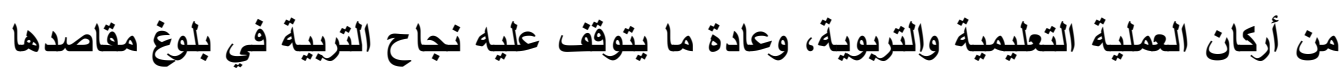
وتحقيق أهدافها. إلا أن مهنة التعليم تنظوي على الكثير من المطالب والأدوار الواجب علي المطلم تحصيلها

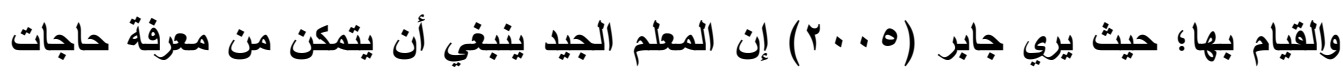

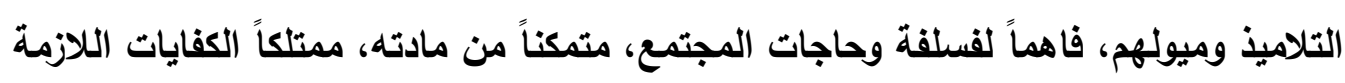

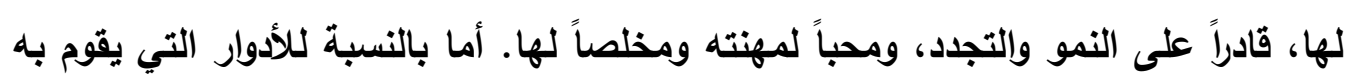

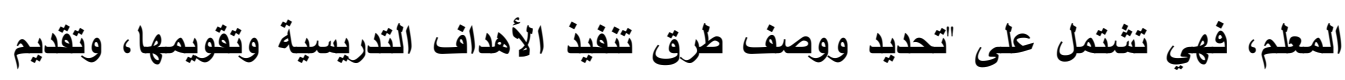

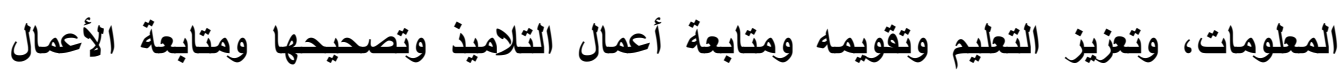

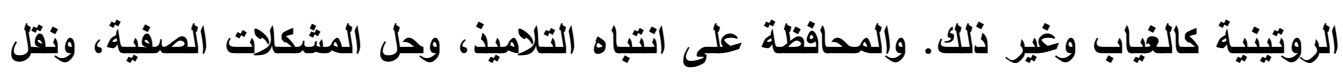


القيم والمثل والعادات الحسنة، وإدارة النشاطات، والتعاون مع الإدارة والزملاء، وأولياء الأمور

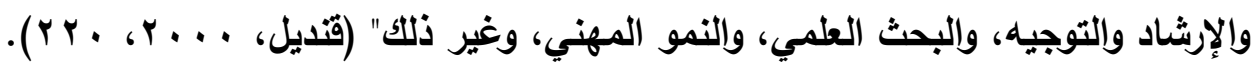
مما سبق يمكن القول: إن مهنة التعليم مهنة كثيرة المطالب وتعتبر من أكثر المهن

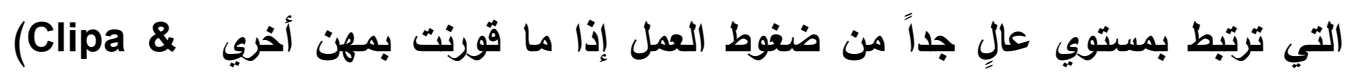

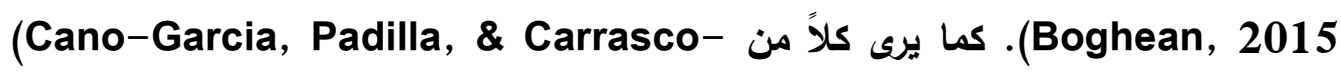
Ortiz, 2005)

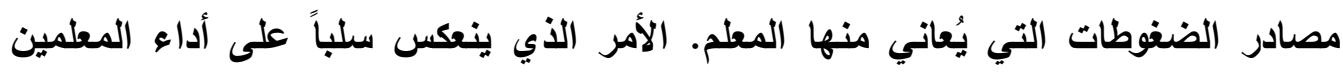

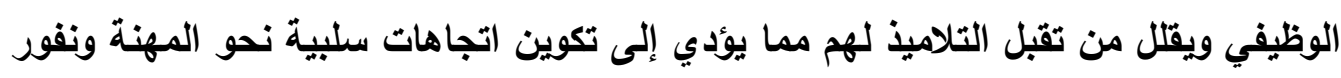
الأفراد منها ونضوبها Sandilos, Goble, Kaufman, \& Pianta, 2018 (Sant).

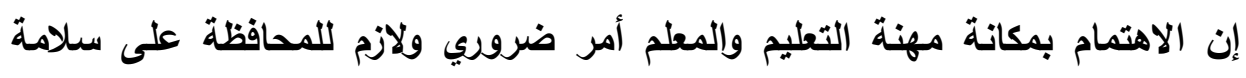

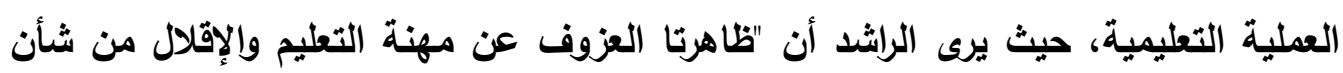

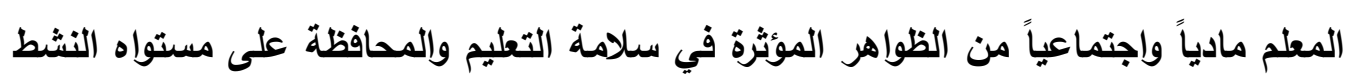

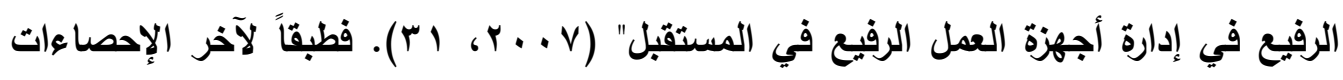

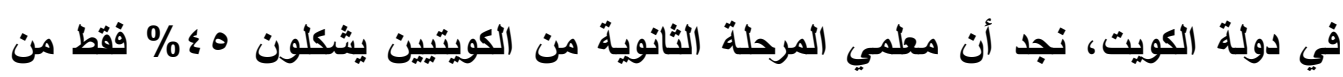

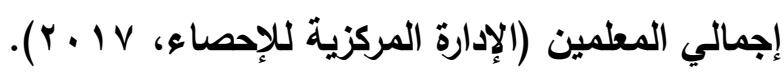

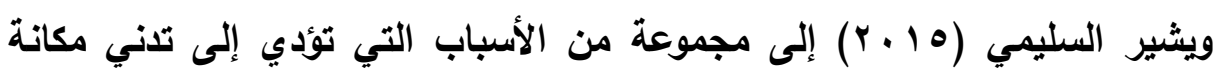

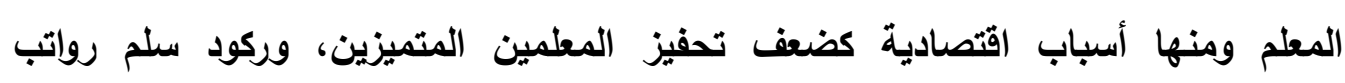

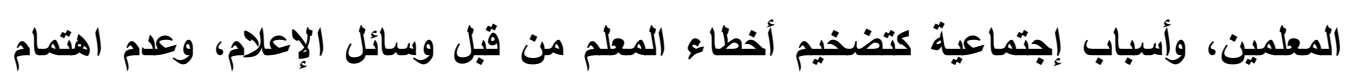

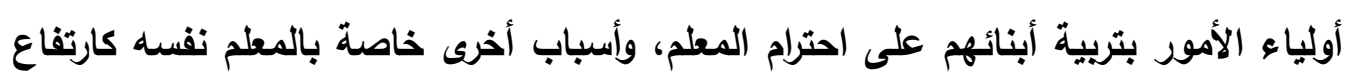

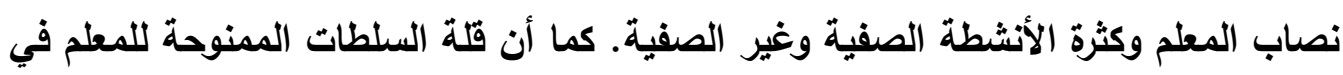

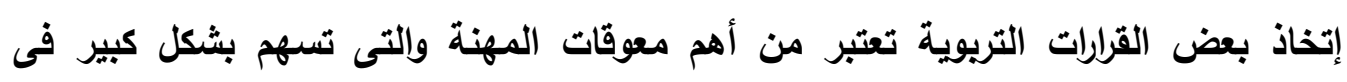
إنغفاض مكانتها (Hall \& Langton, 2006; Sandilos et al., 2018).

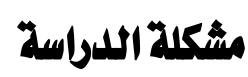

إن مكانة الفرد في مجتمع أو جماعة ما تؤثر إما بالسلب أو بالإيجاب على شعوره،

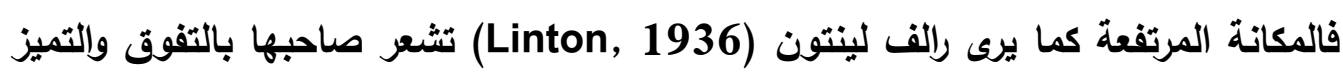


بينما المكانة المنذفضة تثعر صاحبها بالانحطاط والهامشية. كما أن الإحساس بالمكانة

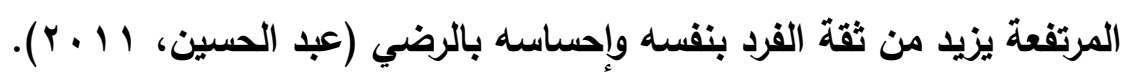

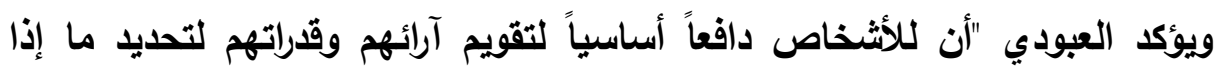

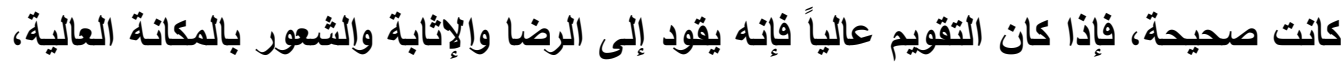

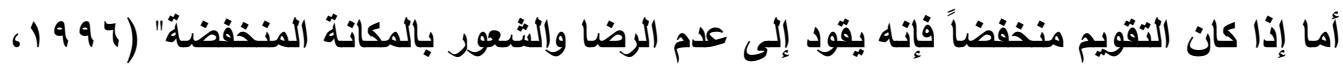

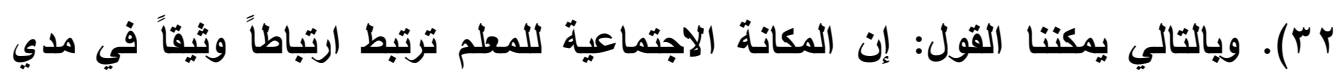

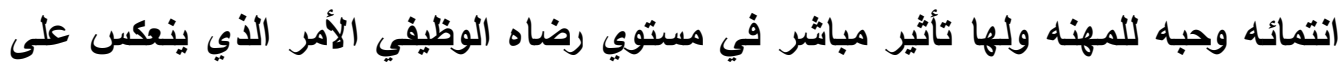
إنتاجيته في العمل. إن دراسة واقع المكانة الاجتماعية للمطلم تعتبر ضرورة ملحة لما لها من انعكاسات

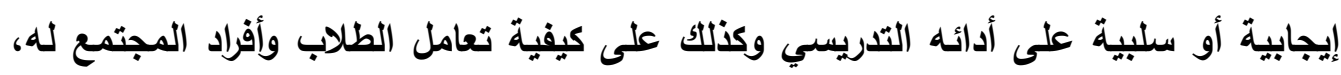
خاصةً في ظل تذمر المطلمين المستمر من سوء أوضاعهم المعيثية وكثرة الأعباء الإدارية

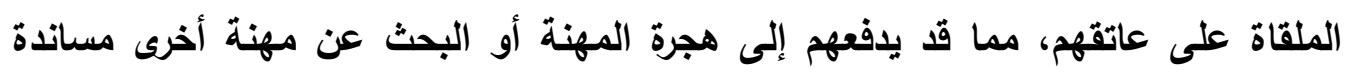
للحصول على دخل إضافي لهم ولأسرهم، الأمر الذي من شأنه أن يثنت البها المعلم فلا يعود قادراً على العطاء والتميز. مما سبق يمكن القول: إن مشكلة الدراسة الحالية تكمن في التثخيص الدقيق لواقع المكانة الاجتماعية للمعلم والتي تتجلى في السؤال الرئيس التالي:

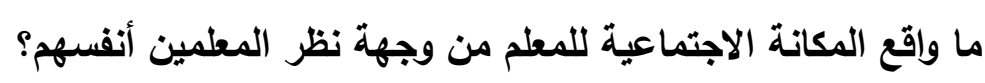
أسئلة الدراسة

تهذف الاراسة الحالية إلى الإجابة عن التساؤلات التالية:

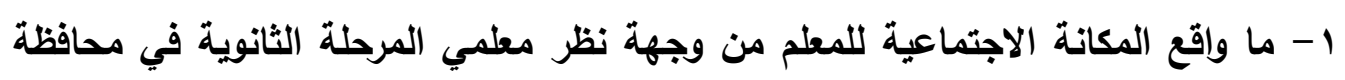

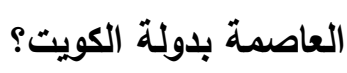
r - هل توجد فروق ذات دلالة إحصائية في المكانة الاجتماعية للمعلم لاى عينة الدراسة تعزي لمتغير الجنس؟

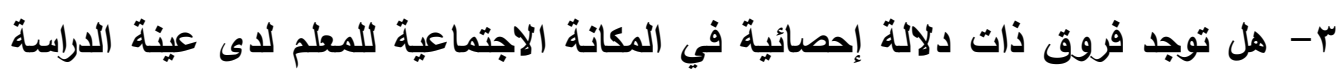
تعزي لمتغير الجنسية؟ 
؛ - هل توجد فروق ذات دلالة إحصائية في المكانة الاجتماعية للمعلم لاى عينة الدراسة تعزي لمتغير التخصص؟

أهداث الدراسة

تسعي الاراسة الحالية إلى تحقيق مجموعة من الأهداف يمكن إيجازها فيما يلي:

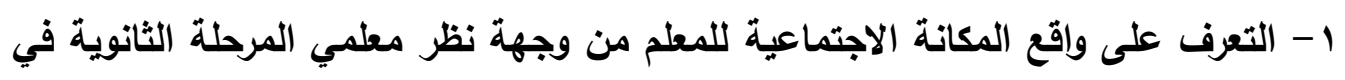
محافظة العاصمة بدولة الكويت. r - الكثف عن الفروق ذات الدلالة الإحصائية بين متوسطات استجابات أفراد عينة الدراسة حول المكانة الاجتماعية للمعلم التي تعزي لمتغير الجنس.

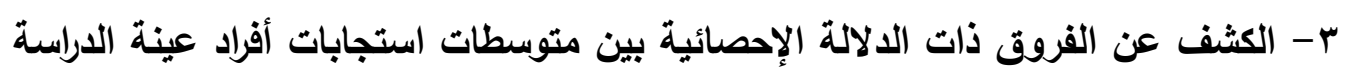
حول المكانة الاجتماعية للمعلم التي تعزي لمتغير الجنسية.

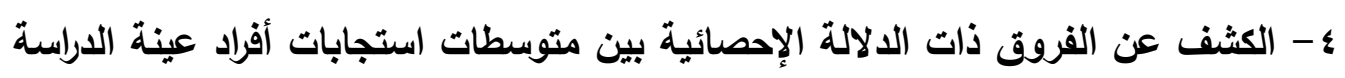

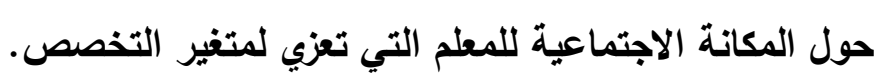
أهمية الدراسلة تكمن أهمية الدراسة الحالية فيما يلي: لإلية 1- أهمية الاور الأي يلعبه المعلم في بناء وإصلاح المجتمع، ودورالمكانة الأجتماعية للمطلم في تعزيز إنتاجيته. r - تسليط الضوء على ما يعانيه المعلم من صعويات ومعوقات، الأمر الذي يساعد متذذي

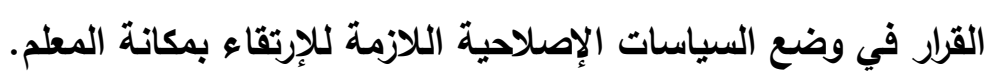
r- ما أثثبته إحدى الدارسات الحديثة عن وجود علاقة ارتباطية طردية ومباشرة بين المكانة الاجتماعية للمطلم والتحصيل العلمي للطالب \&olton, Marcenaro, De-Vries, \& She, 2018)

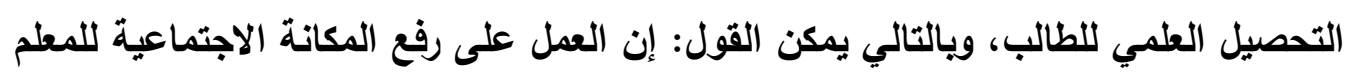

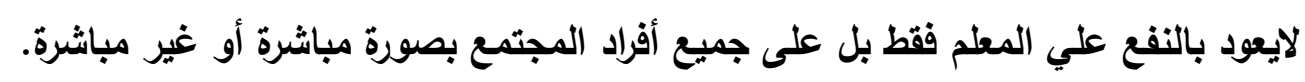

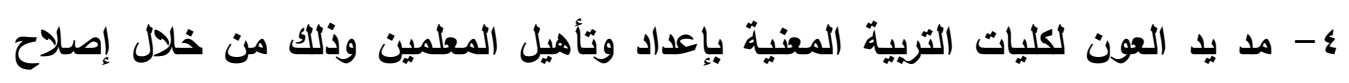

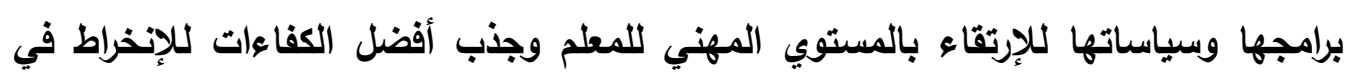
مهنة التطليم. 


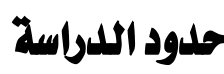

- الحدود المكانية: تثمل جميع المدارس الثانوية الحكومية التابعة لمحافظة العاصمة بدولة الكويت. - الك.

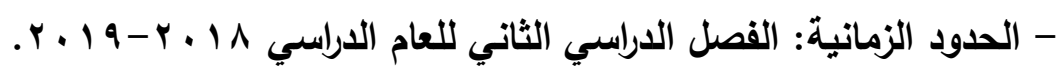

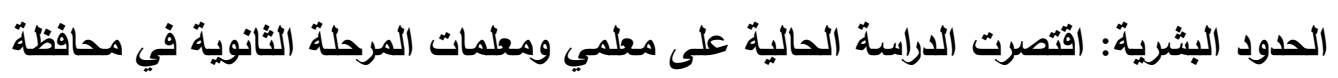

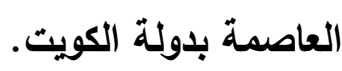

\section{مصطالحات الدراسلة:}

المكانة: تعرف المكانة بأنها "وضع الفرد في تنظيم الجماعة الرسمية وغير الرسمية" (النجار،

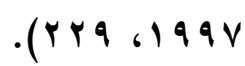
المكانة الاجتماعية: "هي الوضع الذي يحتله الفرد في نسق العلاقات الاجتماعية القائمة في

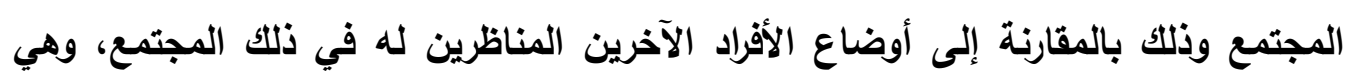

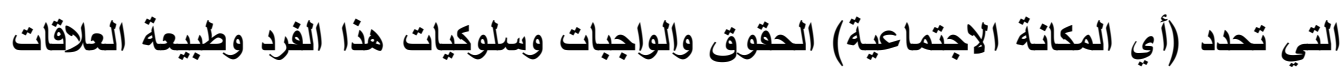

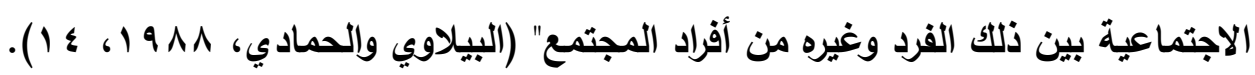

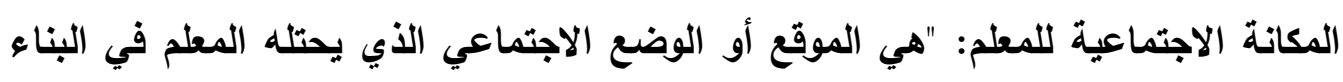

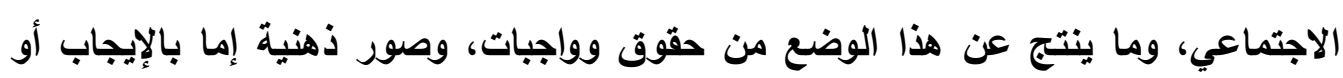

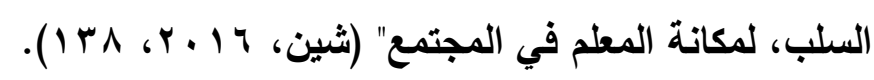

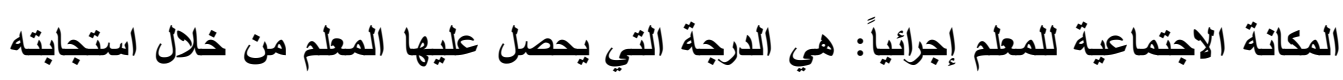
على استبانة المكانة الاجتماعية للمعلم. 


\section{الإطار النظري للداراسة:}

\section{أولاء مثهوم المكانة الاجتمامية}

على الرغم من أن مفهوم المكانة الاجتماعية يعتبر من أكثر المفاهيم أهمية

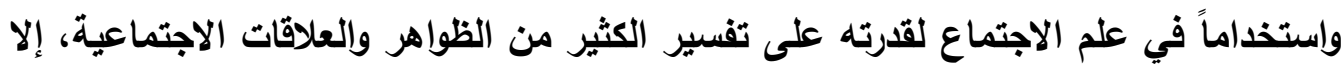
أنه كثيرا ما يحدث نوع من الخلط بينه وبين مفاهيم اجتماعية أخري كمفهومي الدور الأينا الاجتماعي والهيبة (Hargreaves, 2009)، ولذلك نحتاج لتوضيح المقصود من هذه الهين المفاهيم الثلاثة وعلاقتها ببعضها البعض.

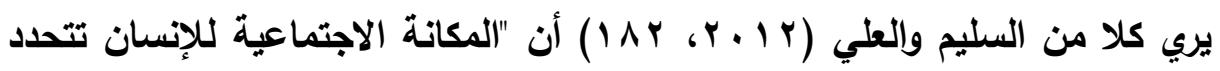

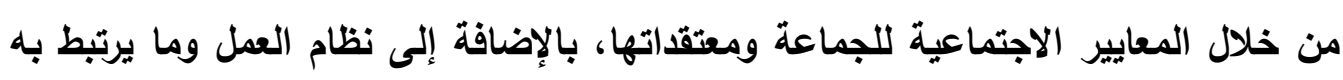

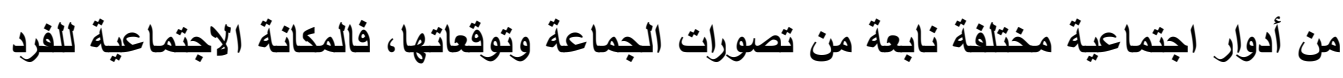

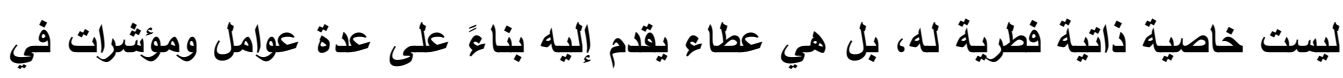

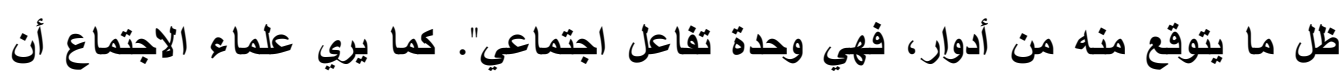

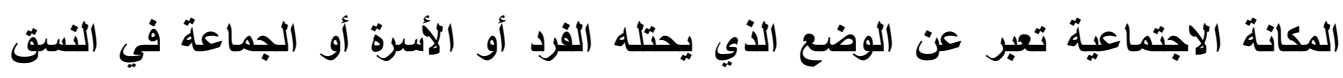

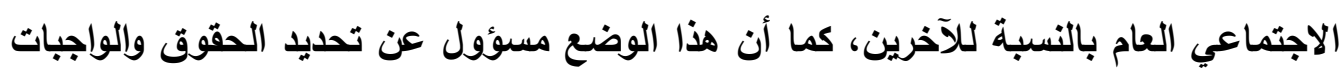

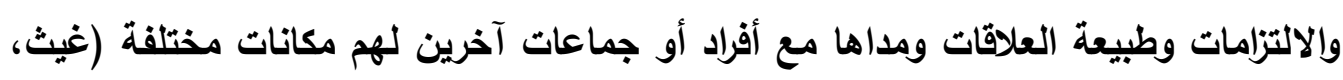

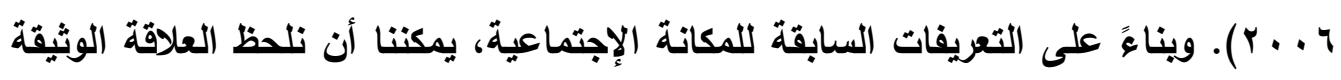

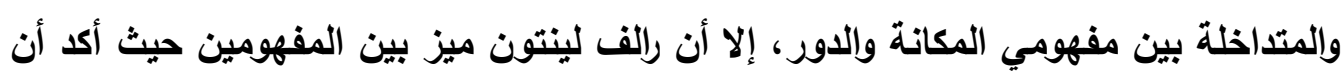

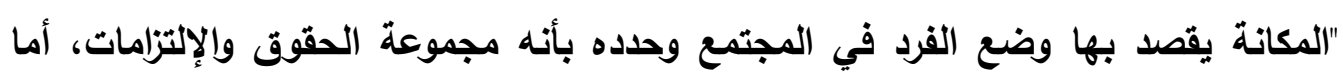

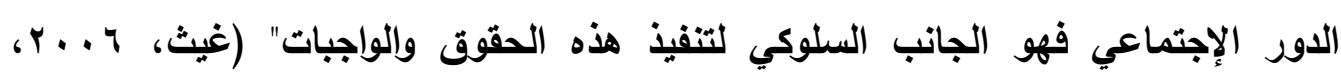

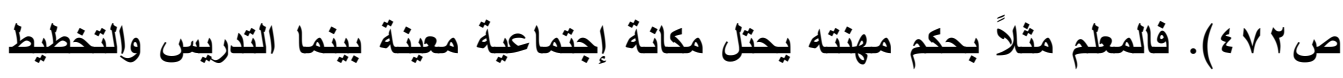

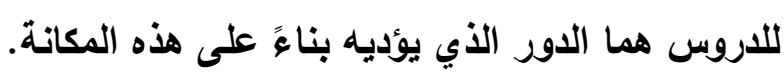

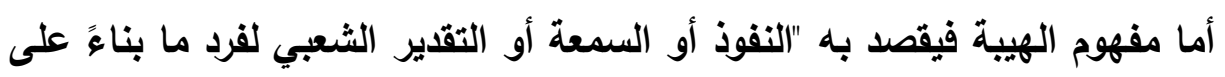
خصائصه الثخصية ومهاراته وإنجازاته وعلاقاته" (Hargreaves, 2009, 217)، فإذاّا

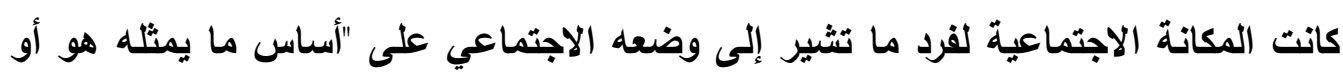

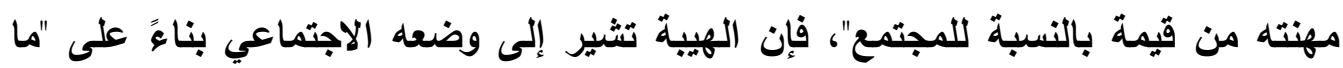

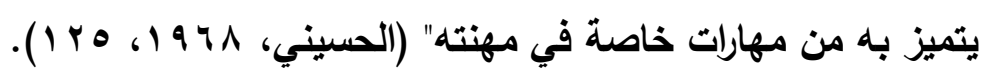




\section{ثانياً: أنهاط المكانة الاجتمامية وأنثمتها}

ويقصد بأنماط المكانة الاجتماعية الوسيلة التي يكتسب بها الفرد أو الجماعة مكانته

بالمجتمع؛ حيث ميز علماء الاجتماع بين نمطين من أنماط المكانات الاجتماعية وهما:

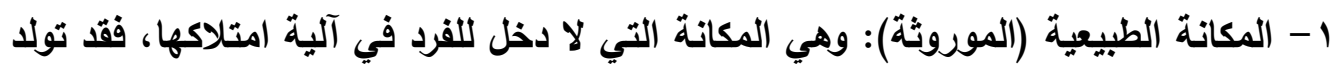

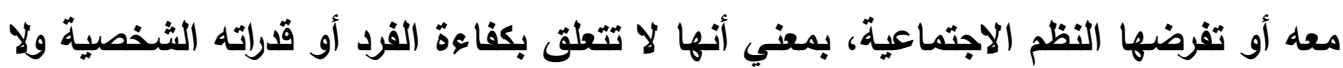

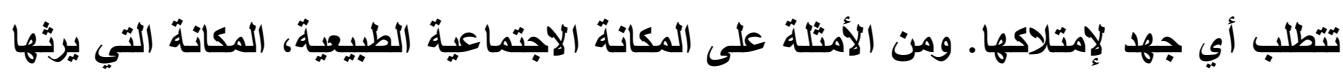
الفرد من أسرته كالنوع، الترتيب بين أفراد الأسرة، العائلة أو النسب، والمباءئلة المواطنة.

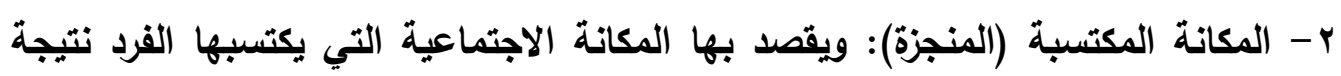
إجتهاداته وقدراته ومهاراته الثخصية مثل الحصول على ولى شهادة تعليمية عليا أو وظيفة

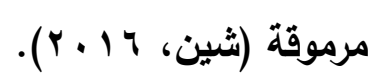

كنلك يمكن تقسيم المكانة الاجتماعية بحسب أنظتها؛ حيث يمكن التمييز بين

$$
\text { نوعين من المكانات الاجتماعية وهما: }
$$

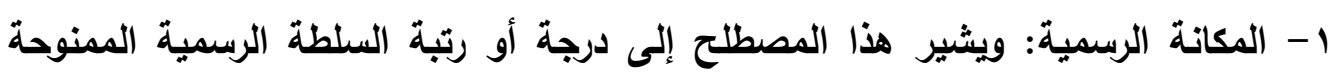

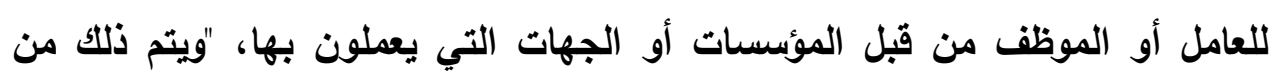

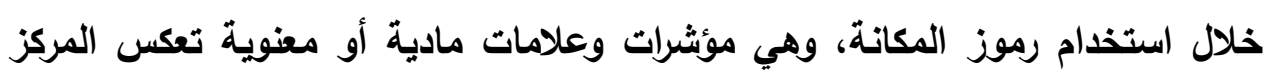

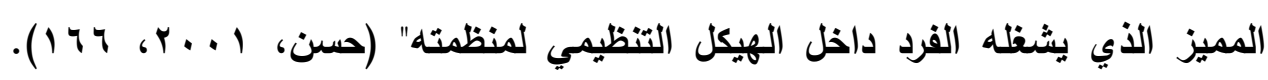

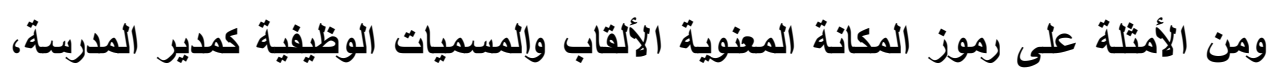

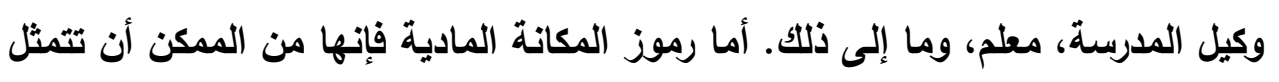
في الظروف الذي يمارس فيها الموظف عمله، كأن يكون لايه مكتب كبير مثلاً ويه العديد من وسائل الراحة.

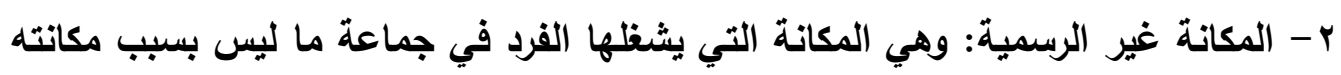

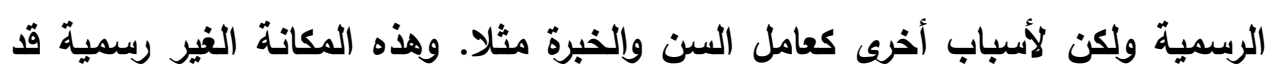

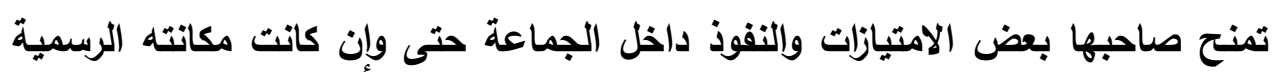

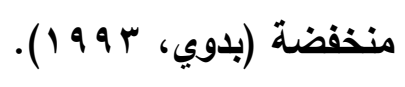




\section{ثالثأ الآثار المترتبة على المكانة الاجتعاعية}

مما لا شك فيه إن امتلاك الفرد لمكانة إجتماعية ما، مرتفعة كانت أو منخفضة،

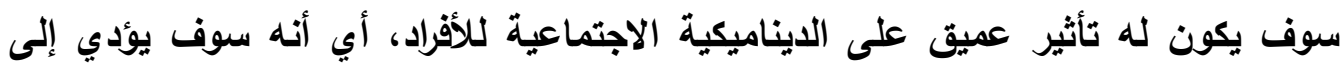
تغيير كبير في شعور وتفكير وسلوك الفرد ذو المكانة الاجتماعية المرتفعة أو المنخفضة،

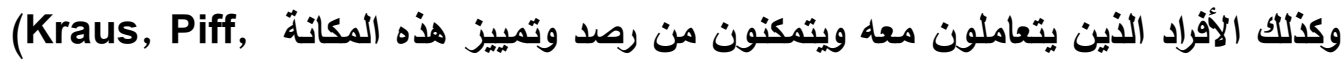
.(Mendoza-Denton, Rheinschmidt, \& Keltner, 2012 ويمكن إجمال الآثار الإيجابية المترتبة على المكانة الاجتماعية العالية في النقاط

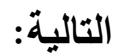
- عادة ما يحظي الأفراد ذوي المكانة الاجتماعية العالية باهتمام وتقدير كبيرين من المحيطين بهر إذا ما قورنوا بأصحاب المكانة الاجتماعية المنذفضة. - يحظون بدرجة نفوذ وامتثال عالية لأوامرهم. - يحظون بفرص أكبر لتطوير مهاراتهم. - يحصلون على قدر كبير من الاعم والمساعدة. - يحصلون على حوافز أو مكافئات أكبر لمجهوداتهم مقارنة بأصحاب المكانة الاجتماعية

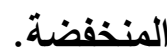
- عادة ما ينظر إليهم على أنهم مؤهلين بشكل جيد حتى ولو افتقدوا الخبرات اللازمة .)((Dubois \& Ordabayeva, 2015; Hardy \& Van, 2006 رابعاً: وطائف المكانة الاجتمامية تقوم المكانة الاجتماعية (في جانبها الإيجابي) عند ارتباطها بمهن وأعمال معينة، بالعديد من الوظائف الهامة والتي يمكن تحديدها فيما لإيلي:

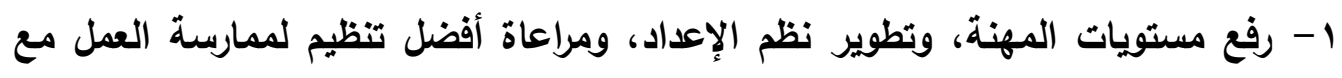
حفز الدافعية وتحسين الأخلاقية. r - كسب رضا الجمهور والمتعاملين بتقيم خدمات أفضل ذات التهنية وزن كيفي مرغوب. ب- ب- تقييم دوري مستمر من أجل نمو مهني مطرد، وللحفاظ على مكاسب المهنة.

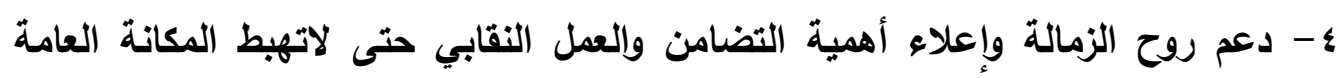

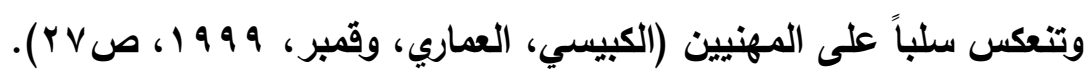




\section{خامساً: معددات المكانة/الاجتمامية}

بالرجوع إلى النمط الثاني للمكانات الاجتماعية، المكانة الاجتماعية المكتسبة والنظر

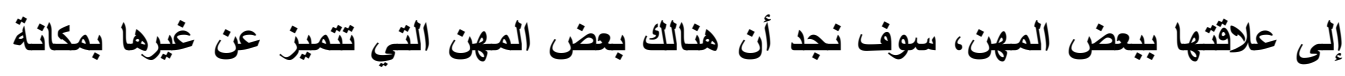

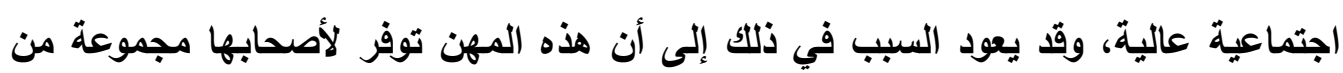

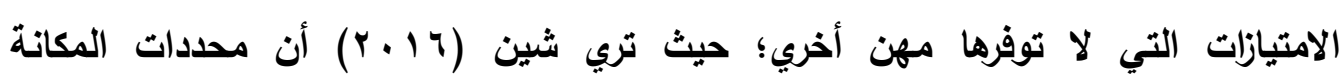

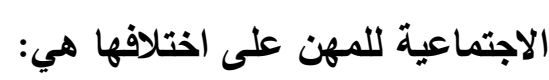
1- الدخل: حيث تزاد المكانة الاجتماعية للفرد او للمهنة بازدياد دخل الفرد أو العائد المادي للمهنة. r- السمعة والتقاير: تعتبر السمعة والتقاير التي يحظي به الفرد أو مهنة من المهن أحد

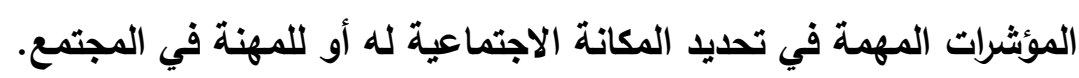

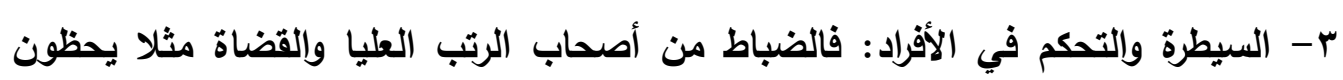

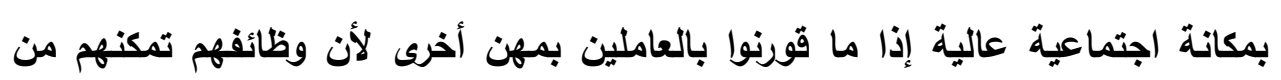

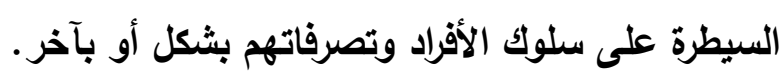

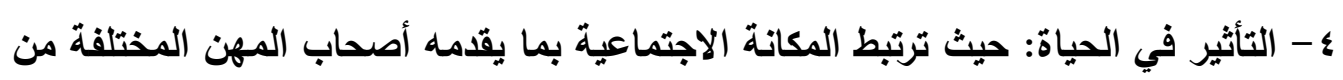

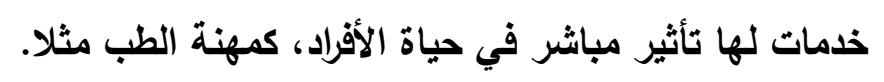

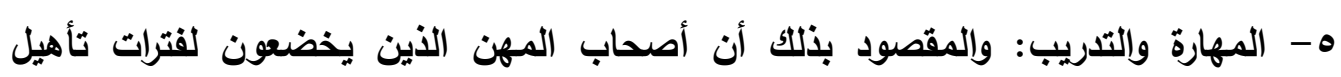

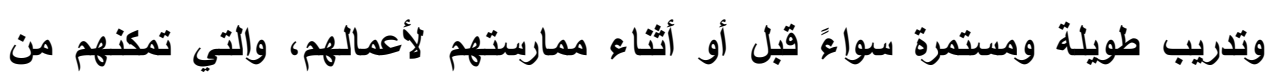

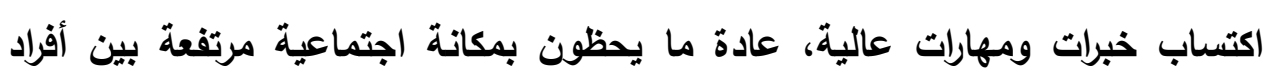

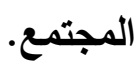

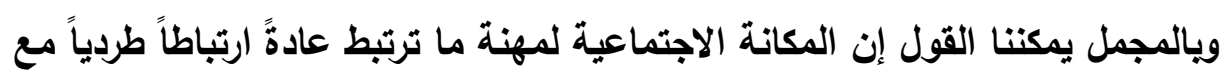

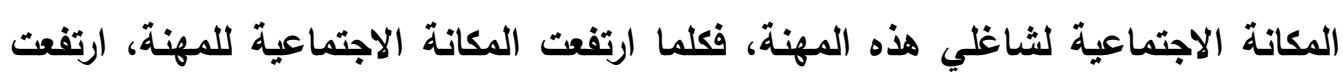
معها المكانة الاجتماعية لثاغلي هذه المهنة، والعكس صحيح. 


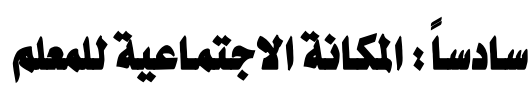

تحظى مهنة التعليم كغيرها من المهن الأخرى بقيمة أومكانة معينة (محددة) في

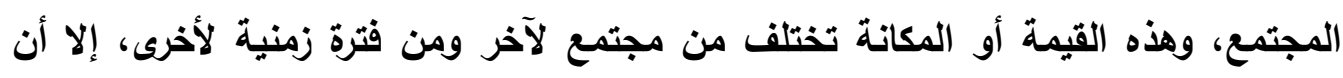

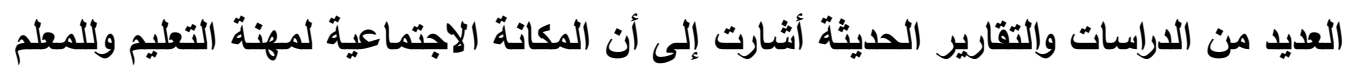

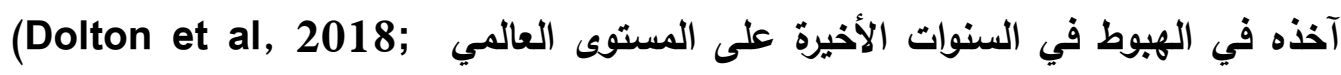
Hargreaves, 2009)

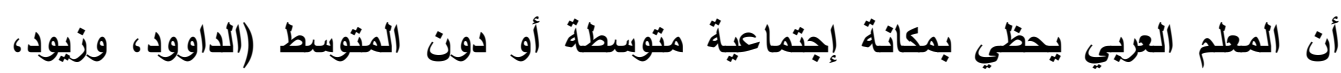

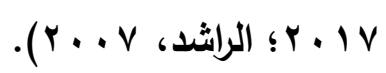

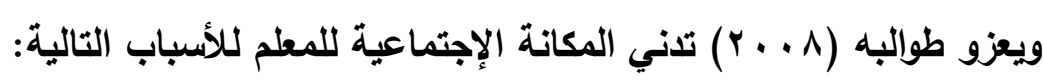

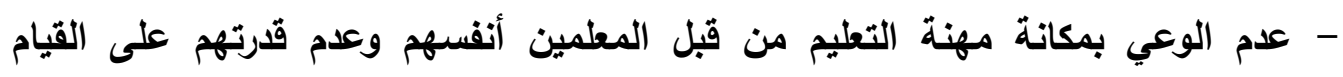

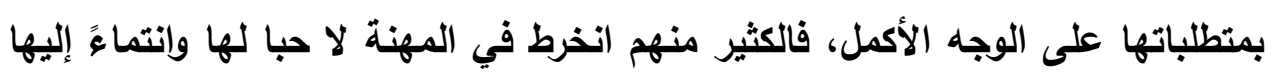
بل لبل لعدم وجود فرص وظيفية أخرى.

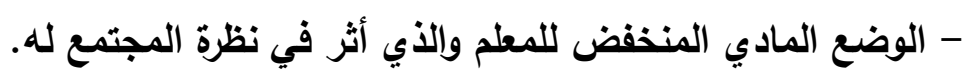

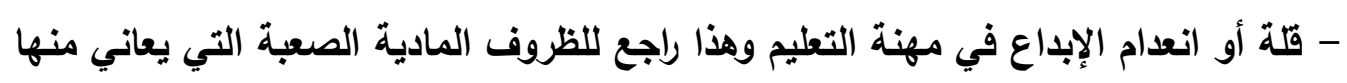

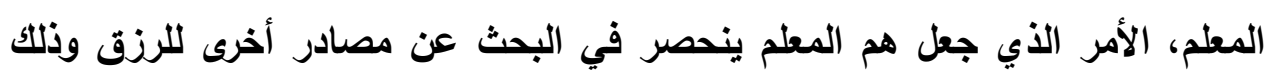

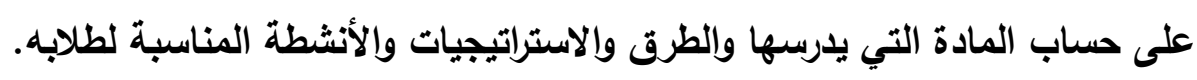

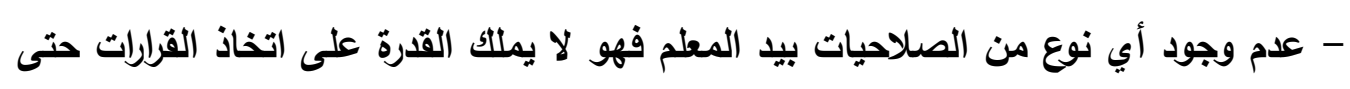

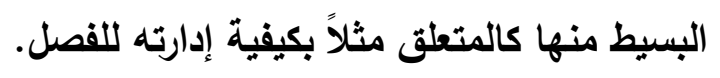

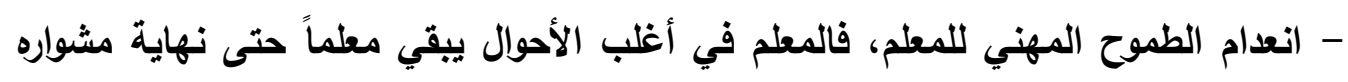

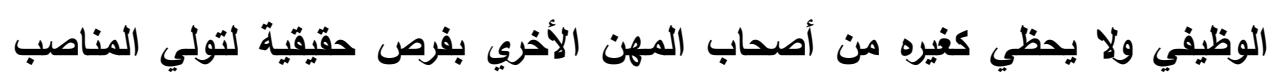

$$
\text { المهمة في الاولة. }
$$

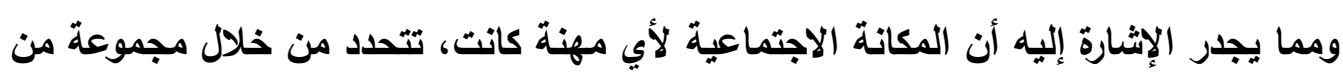

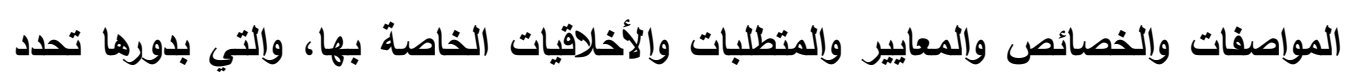
آلية اختيار أعضائها، وتحكم سلوكياتهر. وقد ذكر صافي مجموعة من المعايير المهمة في تحديد مكانة المطلم وهي: 
- أساس معرفي وقاعدة علمية، متثكلة من ثقافة عامة ومتخصصة ومهنية، تثمل معارف تطبيقية ونظرية. - تكوين مهني يؤمن التفاعل المستمر، قبل الخدمة وأثنائها يتماشي مع المستحدثات

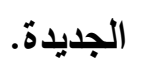
- الاحتراف في المهنة؛ بحيث تصبح حياة دائمة للعمل والنمو.

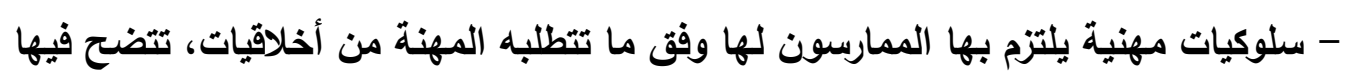

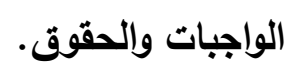
- التمتع بقدر من الاستقلالية. - توجه نحو الخدمة العامة للمجتمع، وتبتعد كل البعلة البعد عن الاستفلال واستعمال المهنة

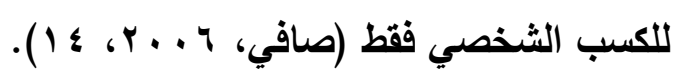

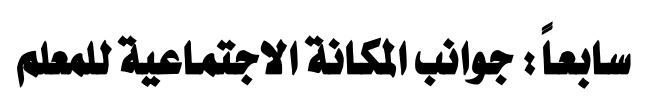

هنالك العلد من الجوانب التي تتحكم بالمكانة الاجتماعية للمعلم، وهذ الجوانب تؤثثر

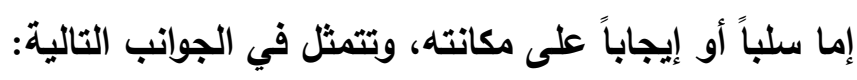

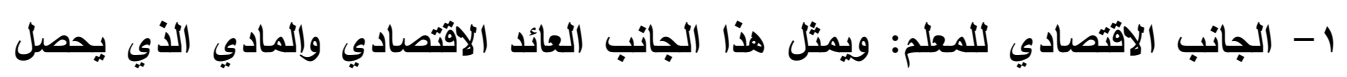

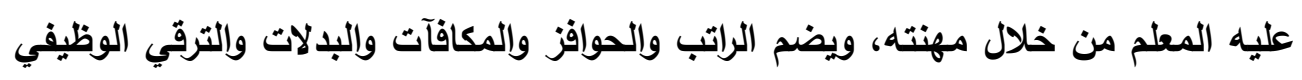

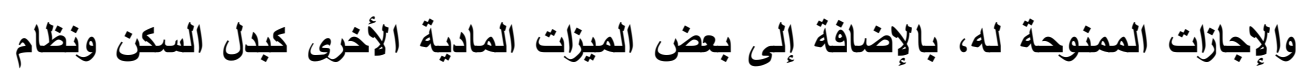

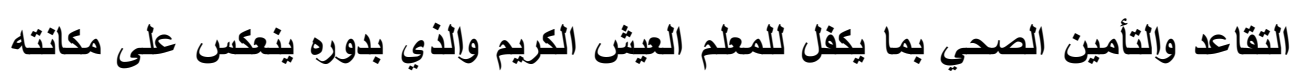
الاجتماعية بين أفراد المجتمع وكذلك بين أصحاب المهن الأخرى.

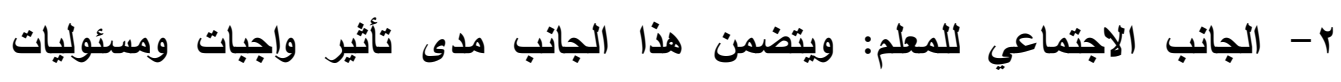

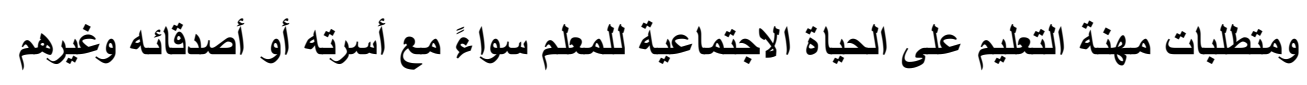

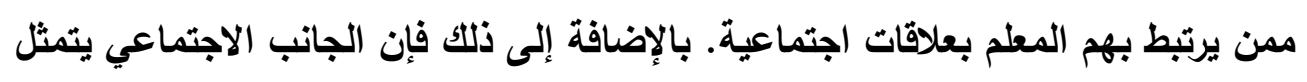

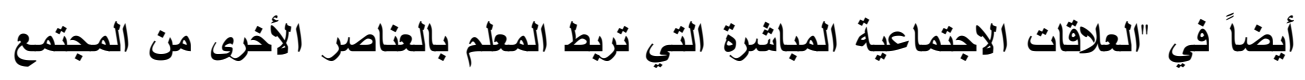

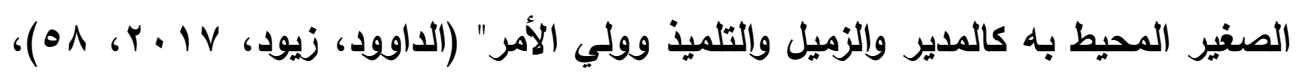
ومدى الاحترام والتقدير الذي يلقاه المعلم منهم.

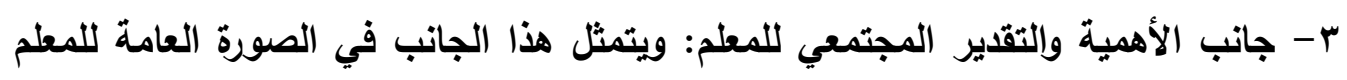

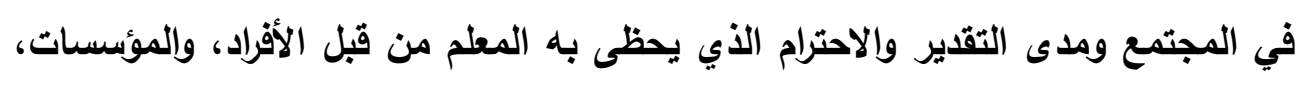


ووسائل الإعلام الرسمية منها وغير الرسمية، وأهيته بالمقارنة مع أصحاب المهن

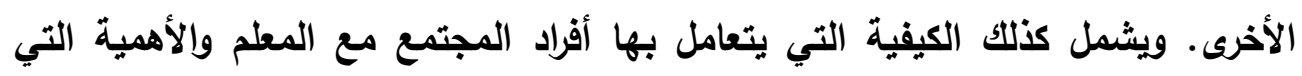

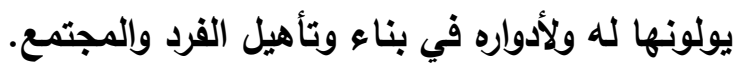

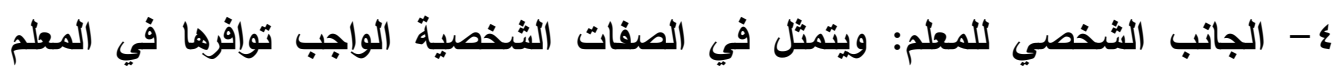

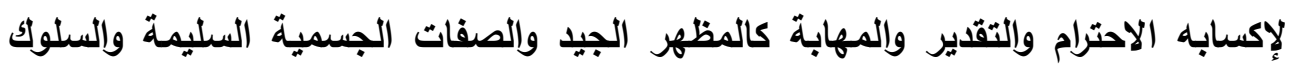

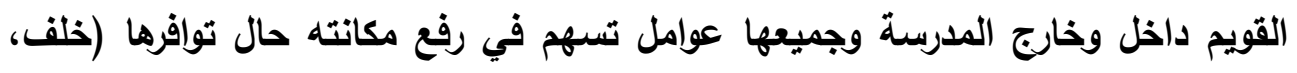

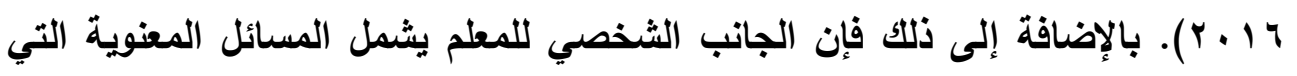

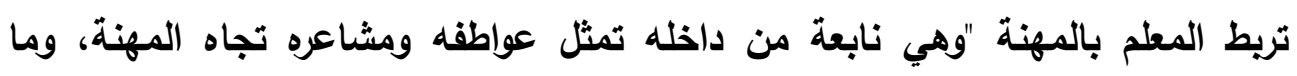

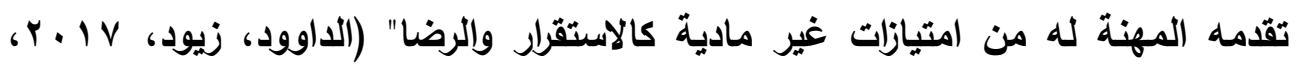
.01

ه- جانب التأهيل التريوي والعلمي للمطلم: ويتمثل في درجة إلمام المعلم بمادة تخصصه وتمكنه منها، ودرجة امتلاكه للمعرفة في التخصصات الأخرى (لريط المواضيع المختلفة ببعضها البعض)، ومدى قدرته على استخدام طرائق التدريس المتنوعة بكفائه التهاته عالية،

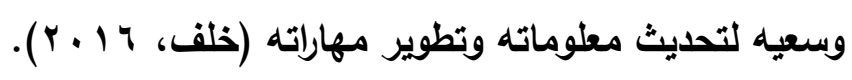

الدراسات السابقة

هدفت دراسة (Opondo, 2002) إلي التعرف علي مدي الرضا الوظيفي لاي

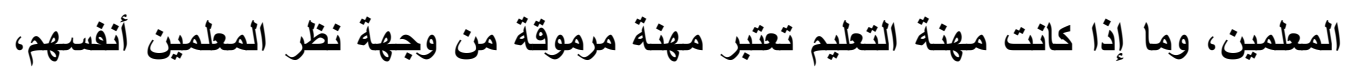

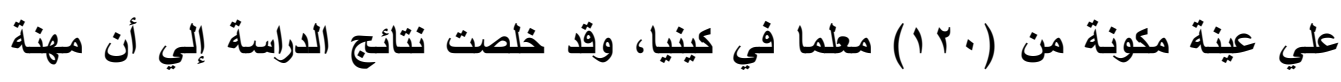

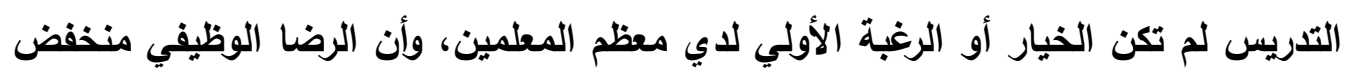

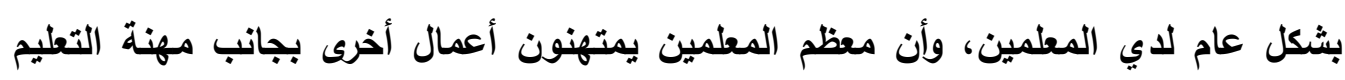

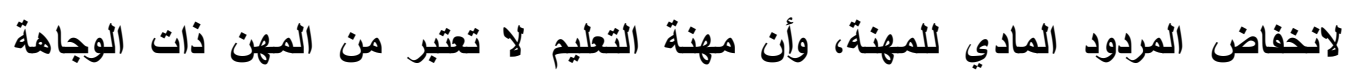

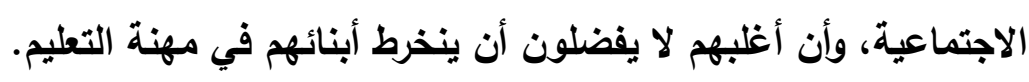

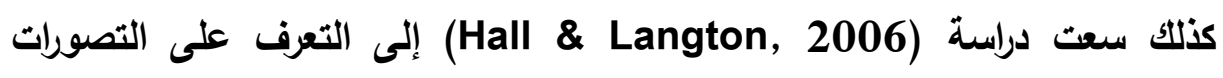
العامة للمجتمع النيوزلندي تجاه المكانة الاجتماعية للمعلم ولمهنة التدريس؛ حيث (التهائ تكونت عينة الدراسة من (1) (1) شخصاً تم استطلاع آرائهم وأخذ استجاباتهم عبر الهاتف. وأثارت الدارسة إلى مجموعة من النتائج المهمة والتي يمكن تلخيصها فيما لئي: 
- حصل المعلم علي المرتبة الرابعة كأعلى مكانة اجتماعية من بين المهن المختلفة من

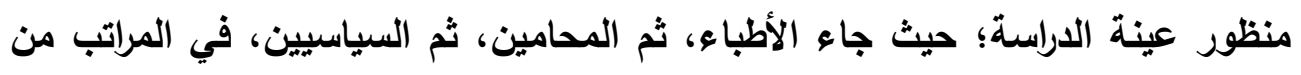
الأولي حتى الثالثة بالترتيب، كنلك فقاء جاء المعلمون بمكانة مساوية لمكانة المحاسبين، الممرضين، والصحفيين.

- أكلات عينة الاراسة أن شخصية المعلم ومهاراته وقدراته هي من أهم السمات التي ينبغي توافرها في المطلم الجيد.

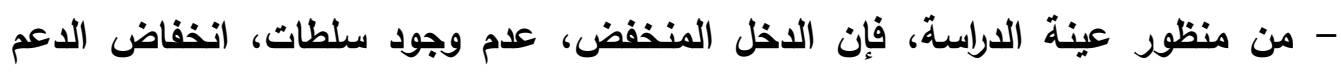

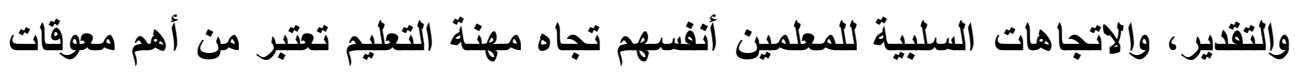

$$
\text { وسلبيات المهنة. }
$$

- أن أهمية التدريس، الضمان والاستقرار الوظيفي، الترقي في الوظيفة، والإجازات الطويلة تعتبر من أهم العوامل الجاذبة لمهنة التدريس.

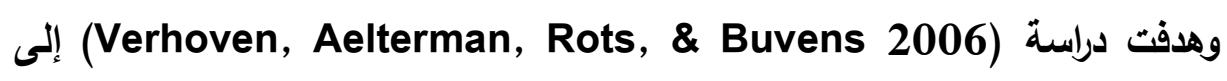

التعرف على المكانة الاجتماعية للمعلم من وجهة نظر المجتمع المحلي في فلاندرز في

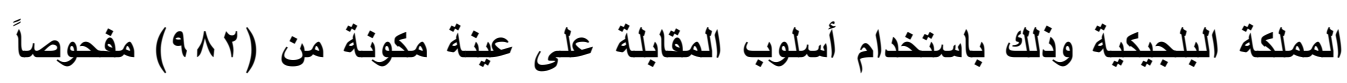

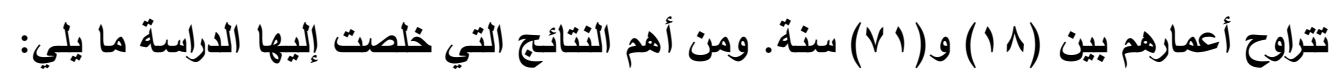

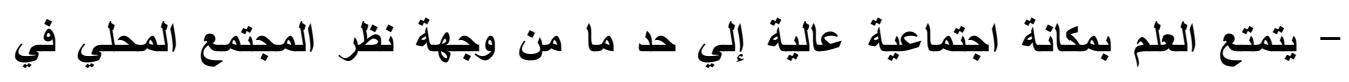
فلاندرز.

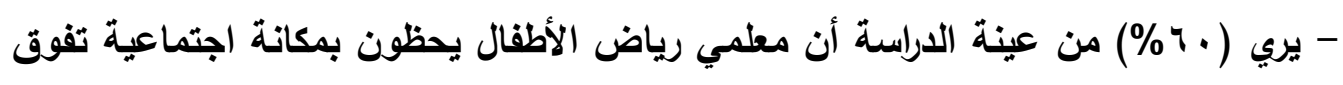

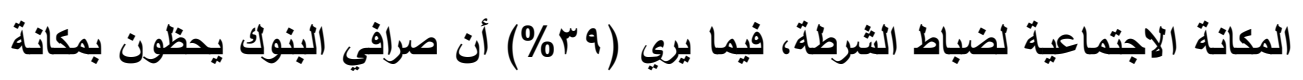
اجتماعية تفوق المكانة الاجتماعية لمعلمي رياض الأطفال.

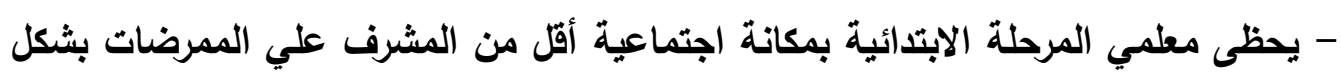

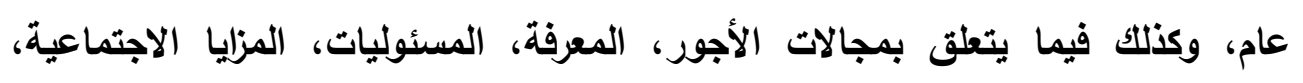
والوجاهة الاجتماعية. - يري ( بr\%) فقط من عينة الدراسة أن معلمي الددارس الثانوية يحظون بمكانة اجتماعية

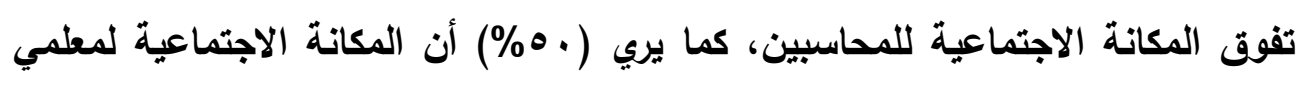


الدارس الثانوية يحظون بمكانة اجتماعية تفوق المكانة الاجتماعية للأخصائيين

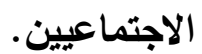

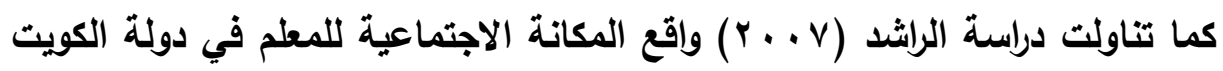
من منظور المطلمين وأولياء الأمور وعلاقتها ببعض المتفيرات كالجنس، الجنسية، المنطقة

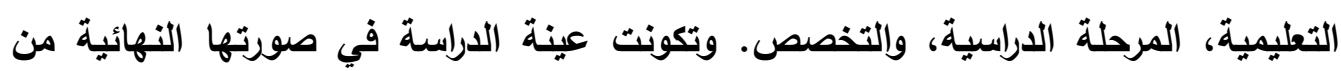
(OIV)

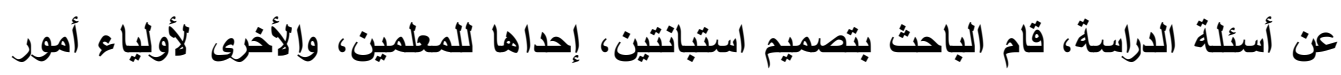

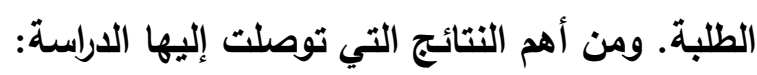

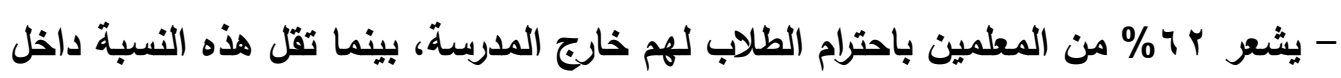
الفصل؛ حيث يشعر بr\% فقط من المعلمين باحترام الطلاب لهم داخل الفصل.

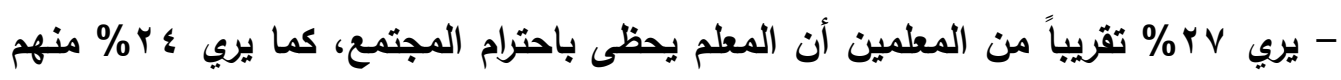

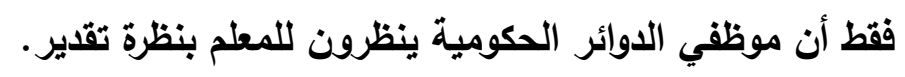
- أن المعلمين الكويتيين يشعرون باحترام التلاميذ لهم بنسبة أكبر من زملائهم المعلمين

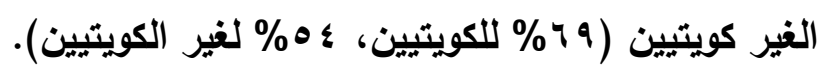

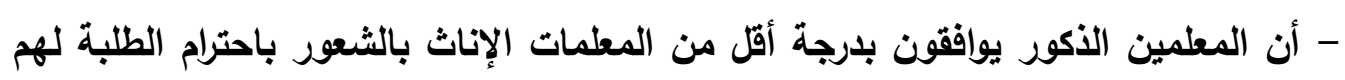
سواءُ خارج المدرسة أو في داخل الفصل.

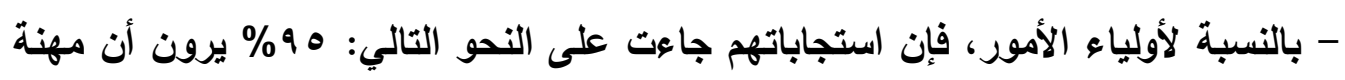

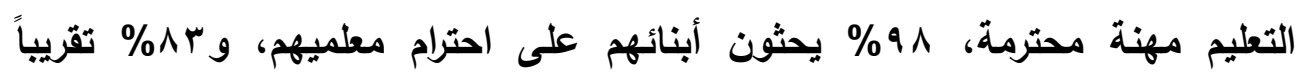
يقترحون رفع أجور المطلمين.

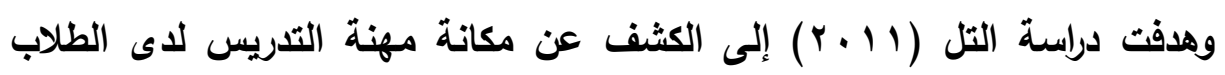

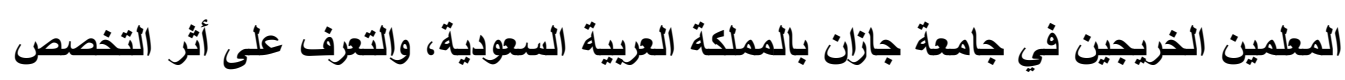

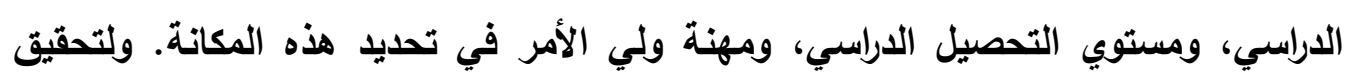

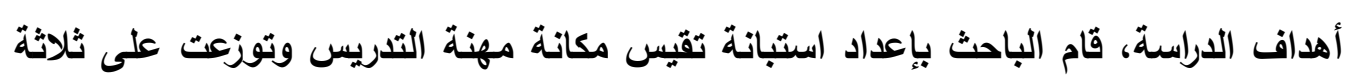

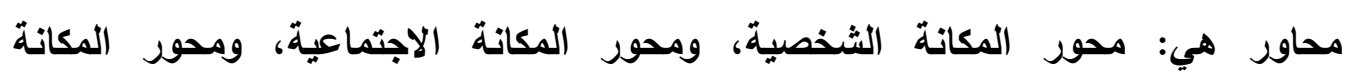

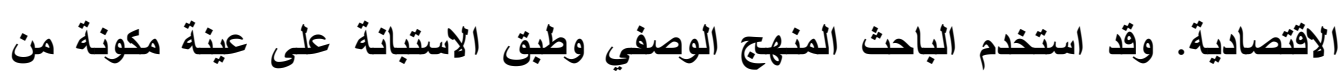

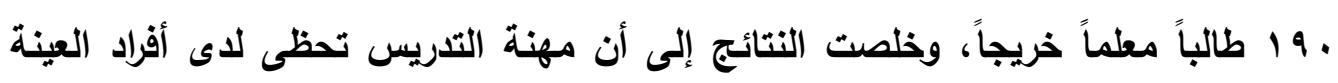


بمكانة شخصية ومكانة اجتماعية عاليتين، وفي حين أنها تحظى لايهم بمكانة اقتصادية

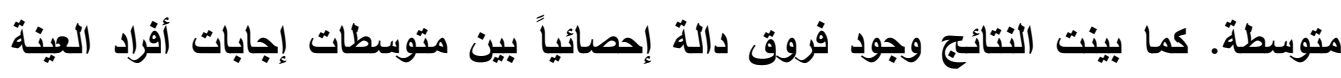

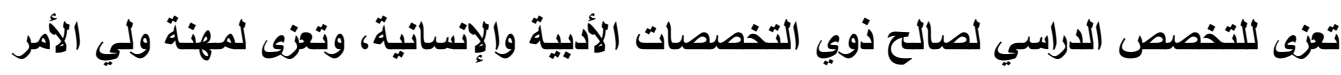

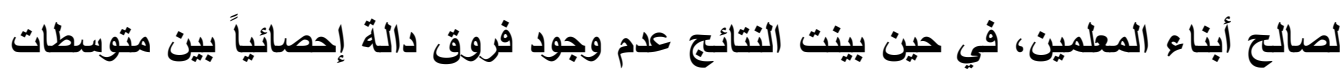
هذه الإجابات تعزى لمستوى التحصيل الدارسي.

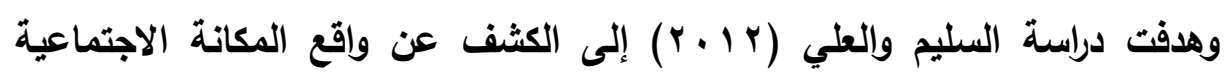

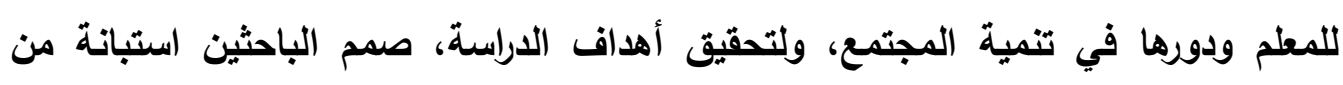

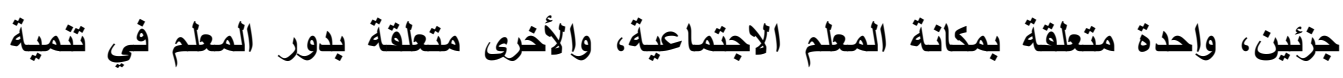

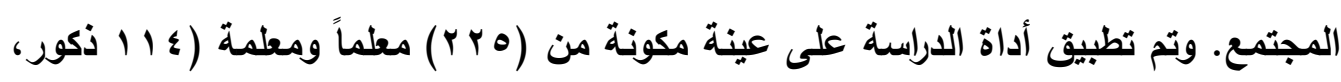
1111 إناث) من معلمي المرحلة الثانوية في محافظة المفرق في المملكة الأردنية. ومن أهم النتائج التي توصلت إليها الدراسة: - وجود علاقة ذات دلالة إحصائية بين المكانة الاجتماعية للمعلم بدوره في تنمية المجتمع من وجهة نظر عينة الدراسة. - أهمية الحوافز والرواتب في رفع المكانة الاجتماعية للمعلم بدرجة كبيرة.

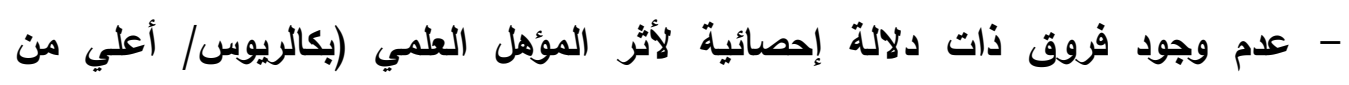
بكالريوس) وسنوات الخدمة في المكانة الاجتماعية للمعلم.

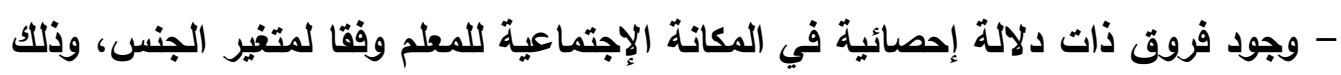
لصالح الإناث.

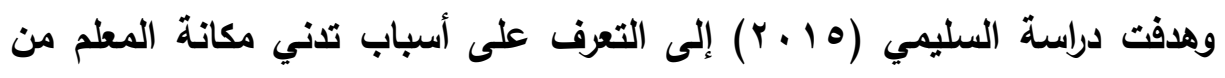

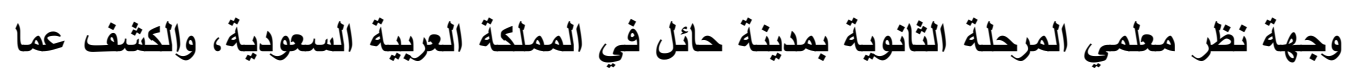
إذا كان هناك فروق دالة إحصائياً حول أسباب تدني مكانة المعلم تعزي إلى متغيرات الثيات المؤهل

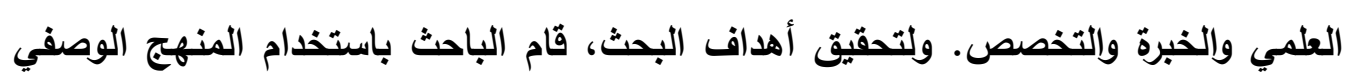

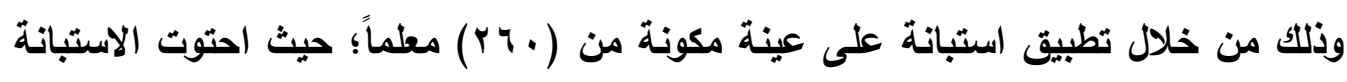

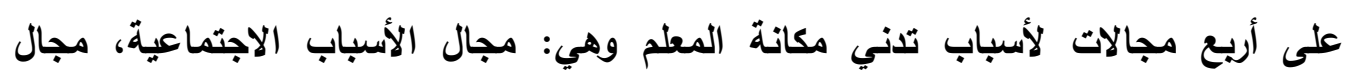

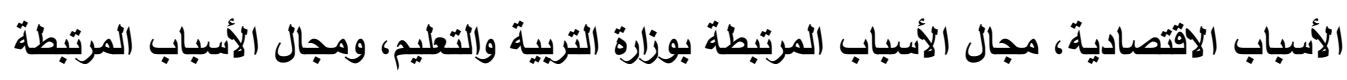

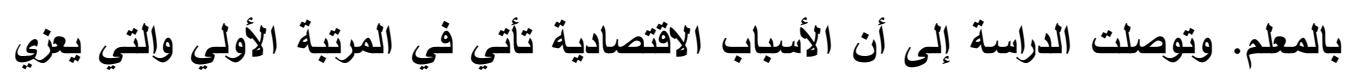




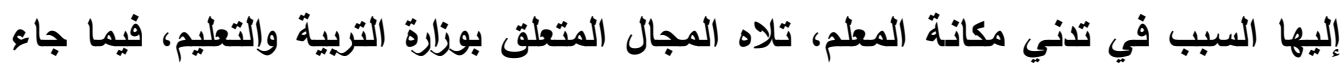
مجال الأسباب الاجتماعية ثالثاً، وجاء مجال الأسباب المرتبطة بالمعلم بالمرتبة الأخيرة.

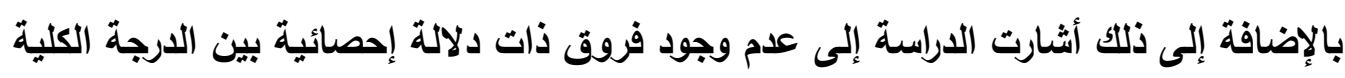

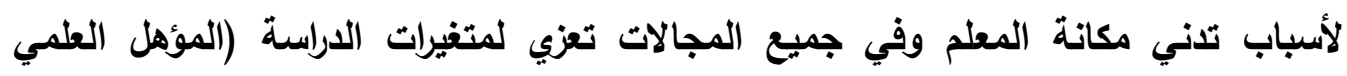
والخبرة والتخصص).

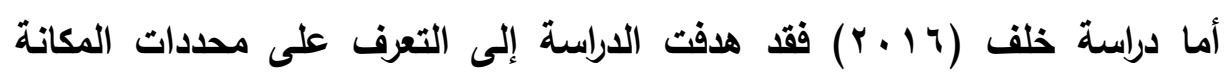

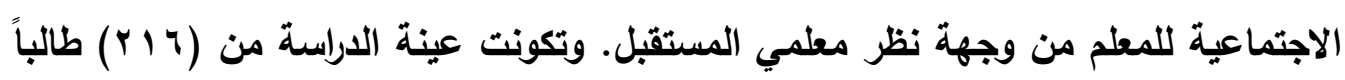

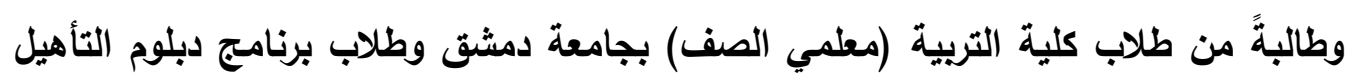

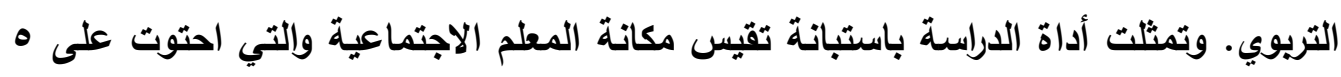

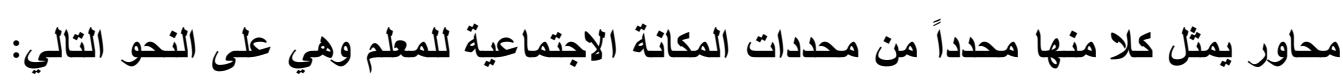

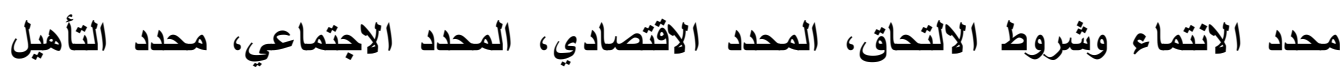

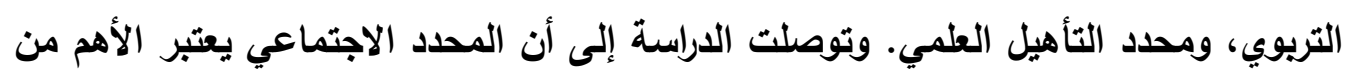

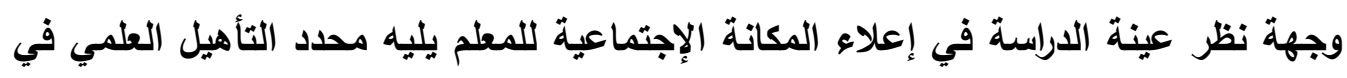

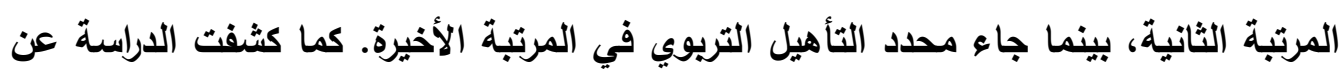

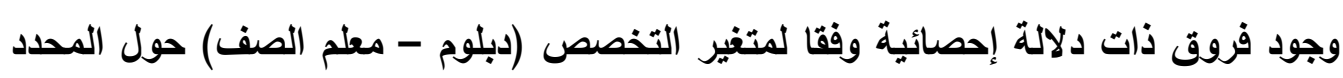

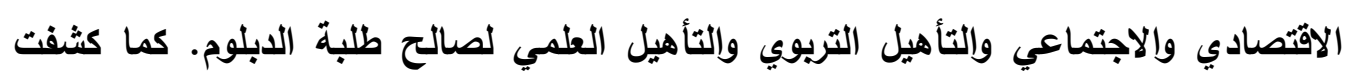

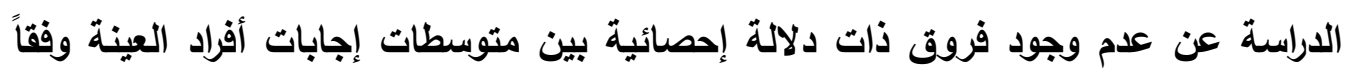

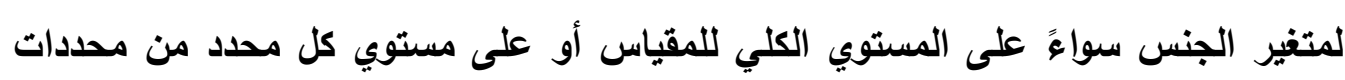
المكانة الإجنماعية.

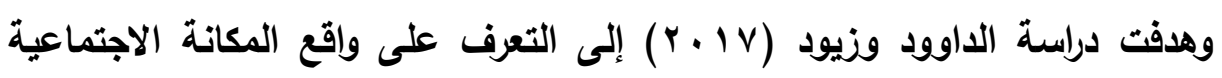

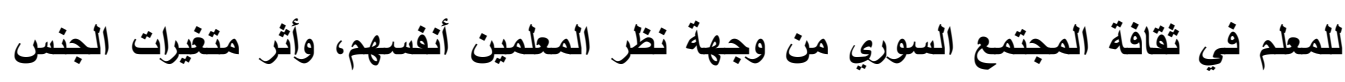

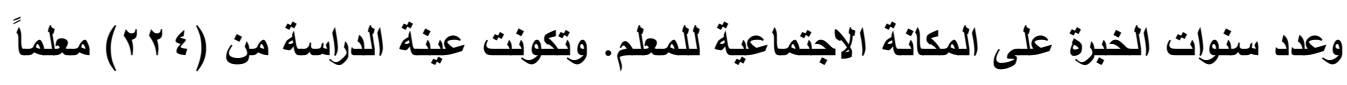

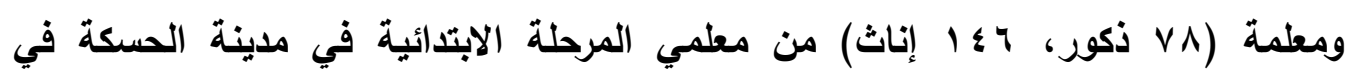

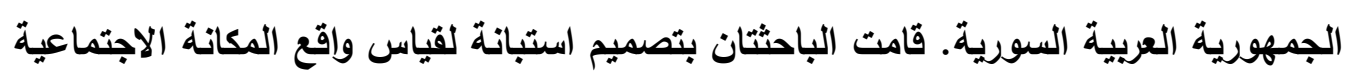

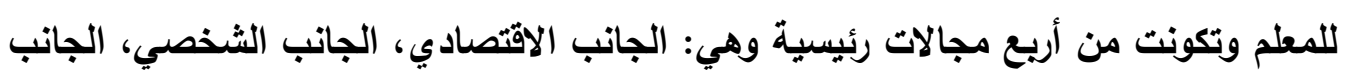

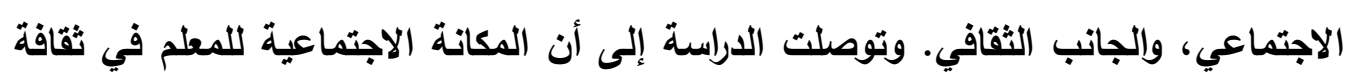


المجتمع السوري بثكل عام وفي الجانب الثخصي متوسطة، بينما كانت منذفضة في

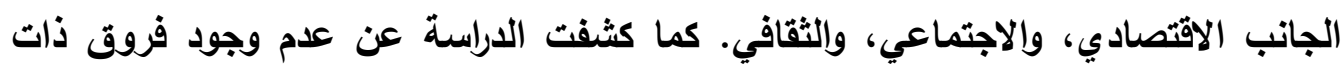

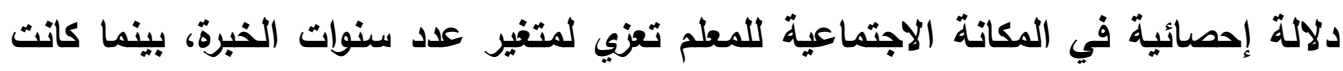

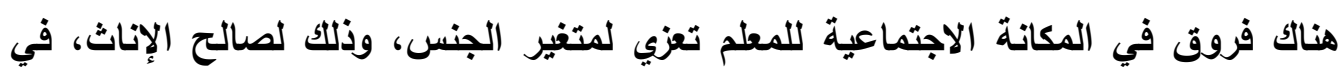

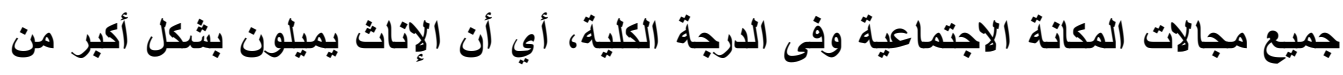

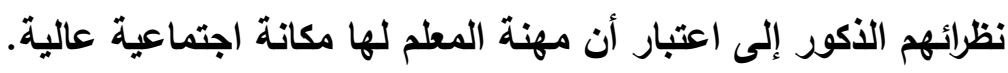

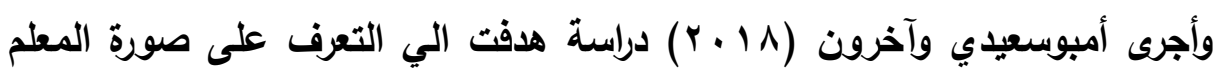

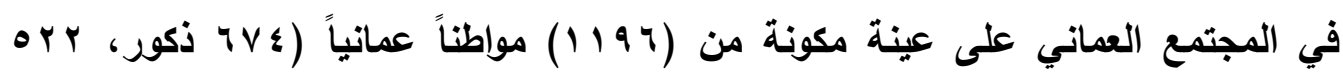

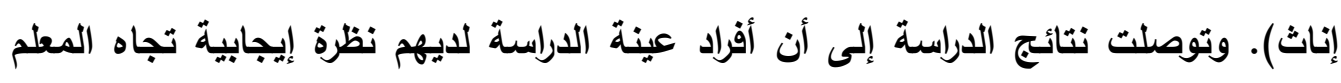

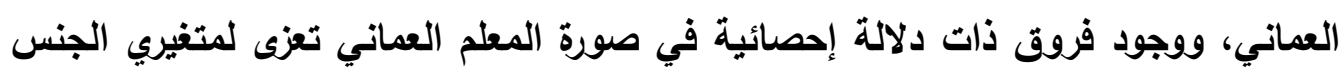

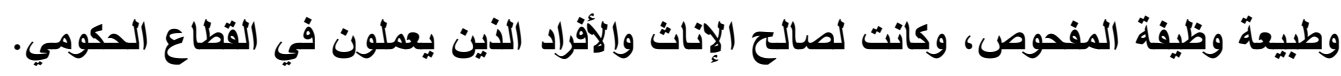

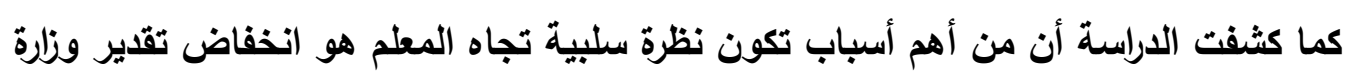

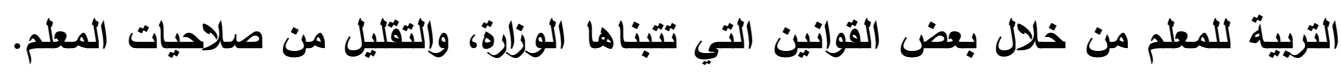

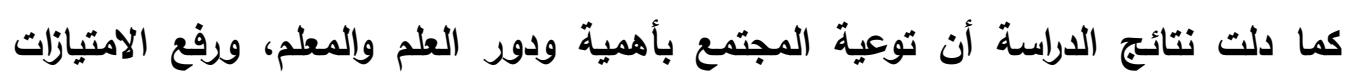

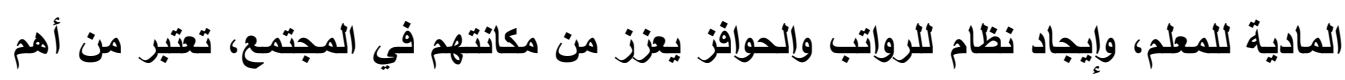

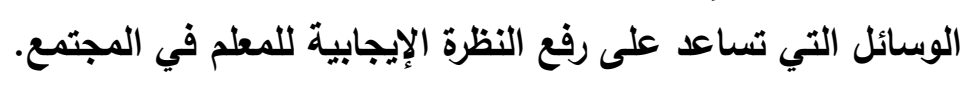

التمايت على الدراسات السابقة

فيما يلي تعليق على الدارات السابقة وموقع الدراسة الحالية منها:

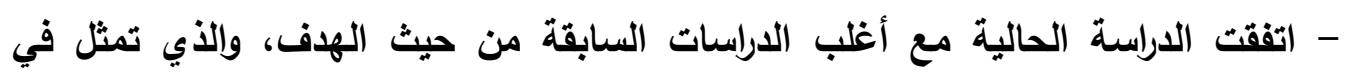

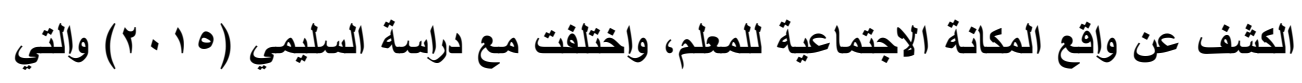

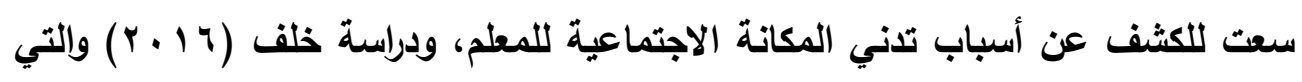

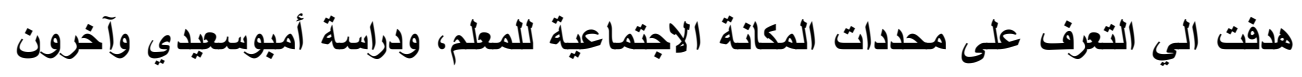

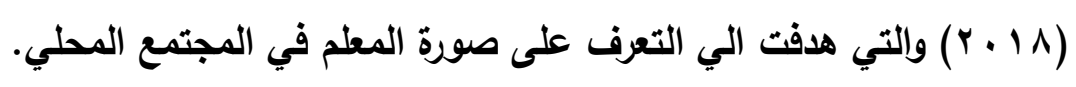

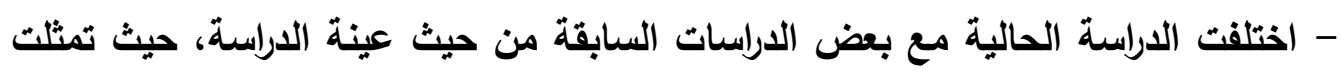

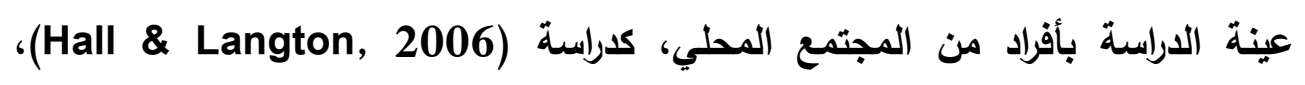

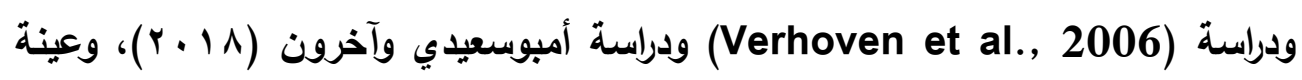




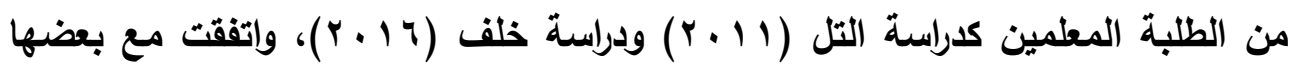
الآخر فتمثلت عينتها في المعلمين أنفسهم، كدراسة (Ypondo, 2002) ودراسة الراشد

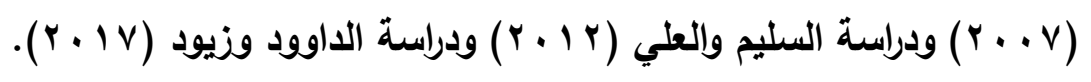

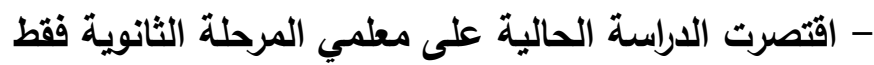
- استفادت الدراسة الحالية من الدراسات السابقة في صياغة فقرات أداة الدراسة، كدراسة

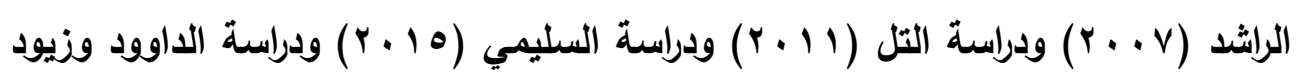

$$
\text { (r.IV) }
$$

- كما استفادت الدراسة الحالية من الدراسات السابقة في تفسير ومناقشة نتائج الدراسة الحالية.

\section{إجراعات الداراسة}

\section{I}

اعتمد الباحث في معالجته لمشكلة الدراسة الحالية على المنهج الوصفي التحليلي لمناسبته لطبيعة الدراسة وأهدافها، فالمنهج الوصفي التحليلي "يهتم برصد ظاهرة أو مشكلة محدة، وتصويرها كميا ضمن فترة معينة أو عدة فترات عن طريق جمع بيانات ومعلومات

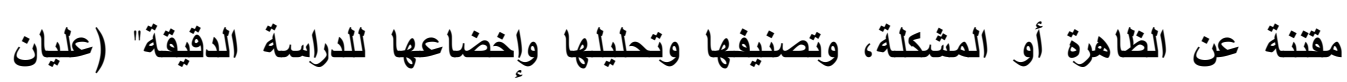

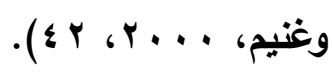

$$
\begin{aligned}
& \text { ب - مجتمع الدداسلة }
\end{aligned}
$$

تكون مجتمع الاراسة من جميع معلمي المرحلة الثانوية بمحافظة العاصمة فى دولة

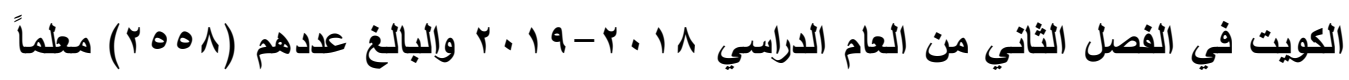

\begin{tabular}{|c|c|c|}
\hline النسبة المئوية & التكرار & الجنس \\
\hline$\% \leqslant 0$ & $11 \leqslant 0$ & ذكر \\
\hline$\% 00$ & $1 \leqslant 1 T$ & أنثي \\
\hline$\% 1 \ldots$ & roON & المجموع \\
\hline
\end{tabular}

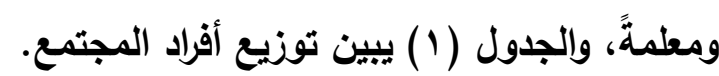
جدول (1) توزيع أفراد مجتمع الدراسة المنة 


\section{ج - عينة الدراسة:}

تم اختيار عينة عثوائية ممثلة لمجتمع الدراسة؛ حيث تم توزيع الاستبانات على العائي

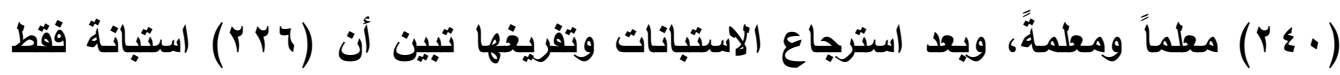
صالحة للتحليل الإحصائي والتي شكلت عينة الدارسة في صورتها النهائية والتي تمثل

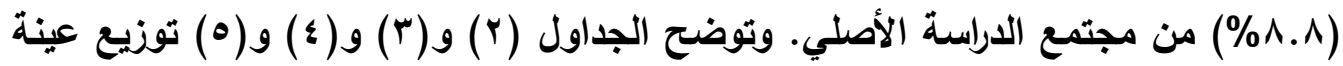

الدراسة حسب متغيرات الدراسة.

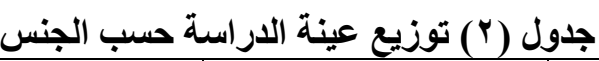

\begin{tabular}{|c|c|c|}
\hline النسبة المئوية & التكرار & الجنس \\
\hline$\% \leqslant V, r$ & $1 . \mathrm{V}$ & ذكر \\
\hline$\% \circ r, V$ & 119 & أنثي \\
\hline$\% 1 \ldots$ & YYT & المجموع \\
\hline
\end{tabular}

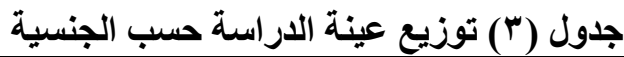

\begin{tabular}{|c|c|c|}
\hline النببة المئوية & لتكرار & الجنسية \\
\hline$\% \leqslant 1, r$ & 94 & كويتي \\
\hline$\% \otimes \wedge, \wedge$ & 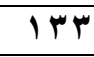 & غير كويتي \\
\hline$\% 1 \ldots$ & YYT & المجموع \\
\hline
\end{tabular}

جدول (؛ ) توزيع عينة الاراسة حسب المدارس

\begin{tabular}{|c|c|c|c|}
\hline النسبة المئوية & 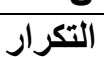 & 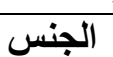 & المدرسة \\
\hline$\%$ \%r,q & إناث & $0 \leqslant$ & ثانوية جمانة بنت أبي طالب للبنات \\
\hline$\% \curlyvee \wedge, \wedge$ & إناث & 70 & ثانوية الروضةً للبنات \\
\hline$\% \times 4,1$ & ذكور & 09 & ثانوية عبد الله الجابر للبنين \\
\hline$\% r, r$ & ذكور & $\varepsilon \wedge$ & ثثانوية يوسف بن عيسى للبنين \\
\hline$\% 1 \ldots$ & & TYT & المجموع \\
\hline
\end{tabular}

أداةالدراسة

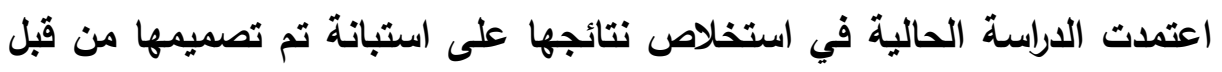
الباحث وذلك من خلال الرجوع إلى الأدبيات والدراسات السابقة ذات العلاقة بموضوع المكانة الاجتماعية للمطم وتضمنت قسمين رئيسين هما: - القسم الأول: يثمل بيانات أولية عامة عن أفراد عينة الاراسة وتثثمل الجنس، الجنسية،

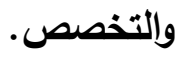


- القسم الثاني: ويثمل الفقرات التي تقيس واقع المكانة الاجتماعية للمعلم؛ حيث كان عددها

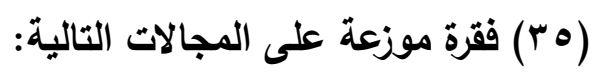

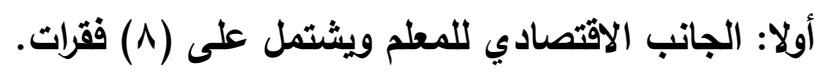

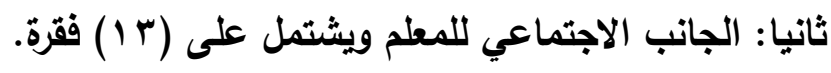

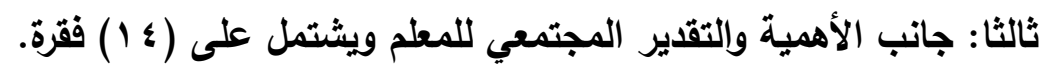

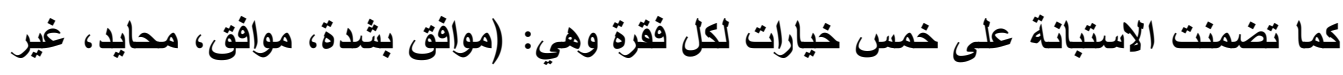

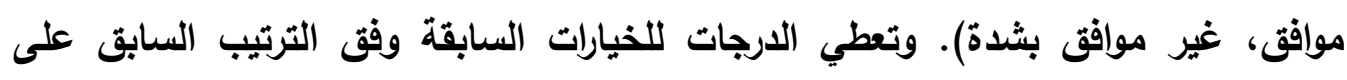

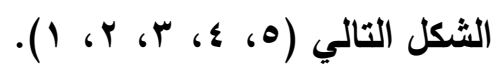

صلدة الأداة

\section{أولاً ؛ الصلدق الطاهري (صداق المحكمين )}

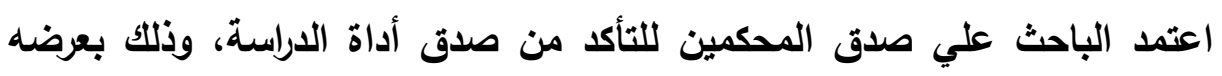

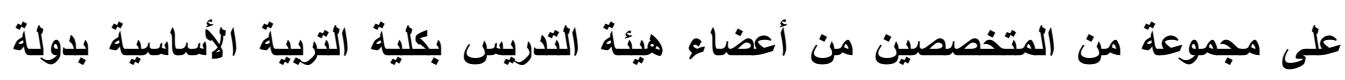

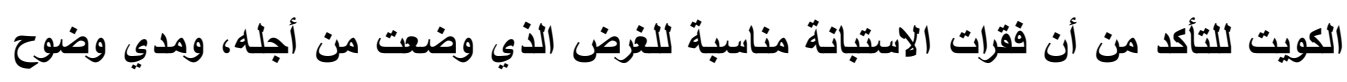

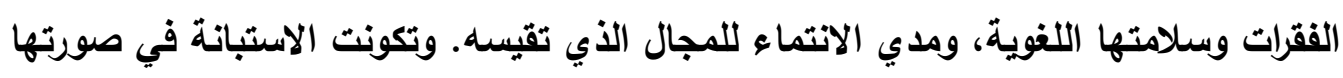

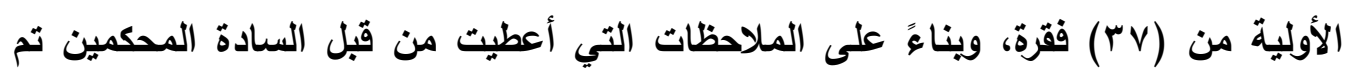

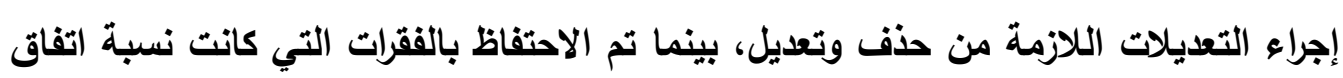

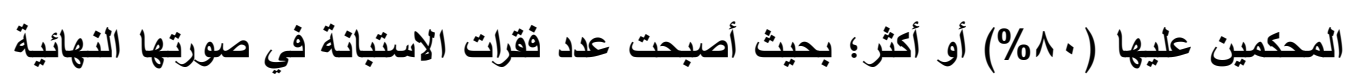

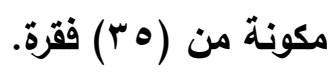

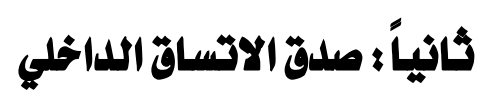
تم التحقق من صدق الاتساق الداخلي للاستبانة وذلك بحساب معاملات الارتباط بين

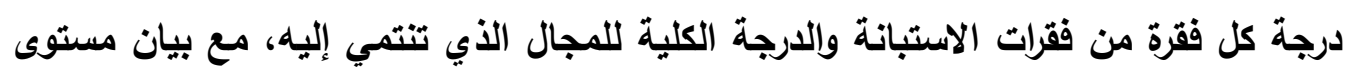
الالالة وجدول (؟) يوضح ذلك. 
واقع المكانة الاجتماعية للمعلم من وجهة نظر معلمي المرحلة الثانوية في محافظة العاصمة بدولة الكويت.

جدول (†) معامل ارتباط كل فقرة بالدرجة الكلية للمجال الذي تنتمي إليه

\begin{tabular}{|c|c|c|c|c|c|c|c|}
\hline الارتباط & الفقرة & الارتباط & رالفقرة & الارتباط & الفقرة & الارتباط & الفقرة \\
\hline$* *, 7 \varepsilon$ & YA & $* *, r V$ & 19 & $* * ., 7 \pi$ & 1. & $* *, 71$ & 1 \\
\hline$* *, \vee \vee$ & pq & $* *,, V V$ & r. & $* *, v^{\prime}$ & 11 & $* *, V 1$ & r \\
\hline$* *, V r$ & $r$ r. & $* *, 9 V$ & rI & $* *, \vee \vee q$ & Ir & $* *, 71$ & $\mu$ \\
\hline$* *, V r$ & $\mu_{1}$ & $* *,, \vee 0$ & rr & $* * ., 79$ & $1 \%$ & $* *, 0 r$ & $\varepsilon$ \\
\hline$* *, 7 r$ & $r r$ & $* *, \vee, 7$ & rr & $* * \cdot, 7$ & 18 & $* *, 7 V$ & 0 \\
\hline$* *, 7 \pi$ & $r \mu$ & $* *, \vee \vee 0$ & $Y \leq$ & $* *, 71$ & 10 & $* *, V \leqslant$ & 7 \\
\hline$* *, 79$ & $r \varepsilon$ & $* *, \wedge r$ & ro & $* *,, \vee \wedge$ & 17 & $* *$, , & $v$ \\
\hline$* *, \Delta q$ & ro & $* *,, V V$ & rq & $* *,, \nabla V$ & IV & $* * \cdot, V_{1}$ & $\Lambda$ \\
\hline & & $* *, \Delta V$ & YV & $* *, \Delta Y$ & 11 & $* *, \ldots q 9$ & 9 \\
\hline
\end{tabular}

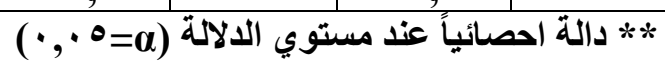

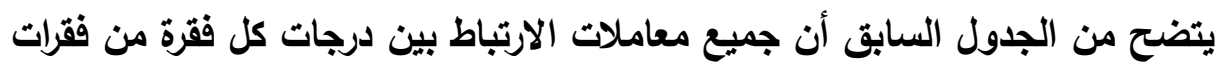

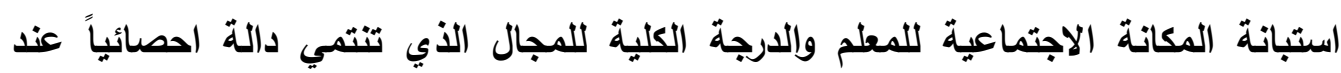
مستوي (ه ., •) مما يال على أن الاستبانة تتميز باجرجة عالية من الصدق.

\section{ثبات الأداة}

تم التحقق من ثبات أداة الدراسة (الاستبانة) بطريقة الاتساق الداخلي وذللك باستخدام معادلة ألفا كرونباخ، وجدول (V) يوضح معاملات ثبات كل مجال من مجالات الاستبانة وكذلك الثبات الكلي للاستبانة. جدول (v) معاملات ألفا كرونباخ لكل مجال من مجالات الاستبانة وللاستبانة ككل الماتل

\begin{tabular}{|c|c|c|}
\hline كرونباخ ألفا & عدد الفقرات & المجال \\
\hline$\cdot, \Lambda Y \cdot$ & $\Lambda$ & الجاتب الاقتصادي للمعلم \\
\hline$\cdot, \wedge \vee \vee$ & 14 & الجاتب الاجتماعي للمعلم \\
\hline. $.9 Y r$ & $1 \leq$ & جاتب الأهمية و التقدير المجتمعي للمعلم \\
\hline$\cdot 9+9$ & ro & الأداة ككل \\
\hline
\end{tabular}

يتضح من الجدول السابق أن قيم معاملات الثبات للمجالات المختلفة للاستبانة

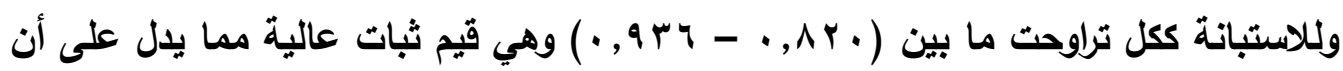
الاستبانة تتمتع بدرجة عالية من الثبات. 


\section{الأساليب الإحصائية المستخدمة في الدراسة}

- للإجابة عن السؤال الأول تم حساب المتوسطات الحسابية والانحرافات المعيارية. كما تم

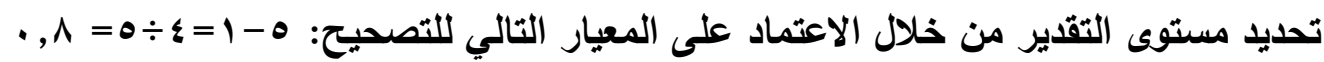

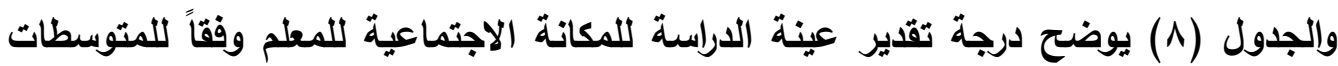
الحسابية جدول (^) درجة تقدير عينة الدراسة للمكانة الاجتماعية للمعلم وفقاً للمتوسطات الحسابية

\begin{tabular}{|c|c|}
\hline درجة التقاير & المتوسط الحسابي \\
\hline منخفضة جداً & $1, \sqrt{9}-1$ \\
\hline منخفضة & $r, \Delta q-1, \wedge$. \\
\hline متوسطة & $r, r q-r, r$. \\
\hline مرتفعة & $\varepsilon, 19-r, \xi$. \\
\hline مرتفعة جداً & $\theta-\varepsilon, Y$. \\
\hline
\end{tabular}

- للإجابة عن السؤال الثاني والثالث واليرابع تم استخام اختبار (ت) الإحصائي.

متثريرات الدراسة

1- اشتملت الدراسة على المتغيرات المستقلة التالية: - الجنس، وله فئتان: ذكر، أنثى. - الجنسية، ولها فئتان: كويتي، غير كويتي،

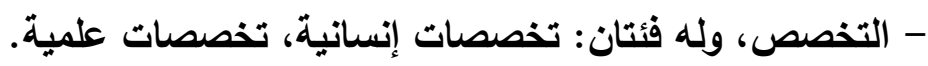
r- المتغير التابع: المكانة الاجتماعية للمعلم لاى مطلمي المرحلة الثانوية في محافظة

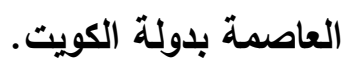

\section{ثتائج الدراسة ومناقتشتها}

للإجابة عن السؤال الأول: ما واقع المكانة الاجتماعية للمعلم من وجهة نظر معلمي المرحلة الثانوية في محافظة العاصمة بدولة الكويت؟ تم حساب المتوسطات الحسابية والانحرافات المعيارية والرتبة والتقلير لجميع مجالات المكانة الاجتماعية للمعلم وليلأداة ككل من وجهة نظر المعلمين أنفسهم، وجدول (9) يوضح ذلك. 
جدول (9) المتوسطات الحسابية والانحر افات المعيارية والرتبة ودرجة التقدير لجميع مجالات المكانة الاجتماعية للمعلم

\begin{tabular}{|c|c|c|c|c|}
\hline درجة التقدير & الرتبة & الالمعراف & المستوسط & أبعاد الاستبانة \\
\hline منخفضة & $r$ & $\cdot, V \otimes V$ & $r, r$. & الجانب الاقتصادي للمعلم \\
\hline مرتفعة & 1 & $\cdot, 7 \vee \mu$ & $r, \varepsilon$. & الجانب الاجتماعي للمعلم \\
\hline منخفضة & $r$ & $\cdot, \vee \bullet \wedge$ & $r, 07$ & جاتب الأهمية و التقاير المجتمعي \\
\hline متوسطة & - & $\cdot, 7 \cdot 1$ & $r, \wedge 1$ & الارجة الكلية \\
\hline
\end{tabular}

يتبين من جدول (9) أن المتوسط الحسابي لاستجابات أفراد عينة الدراسة على الى

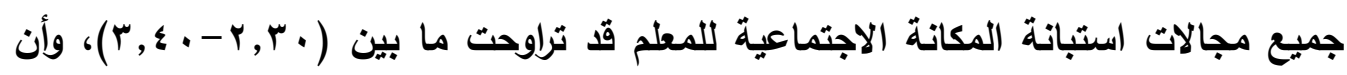

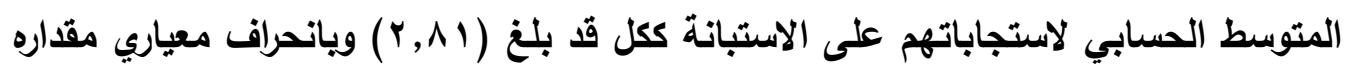
$\cdot(\cdot, 7 \cdot \Lambda)$

وقث جاء مجال الجانب الاجتماعي للمعلم بالرتبة الأولي، بمتوسط حسابي يبلغ (• \&,؟ץ)

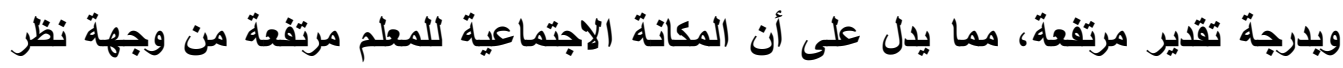

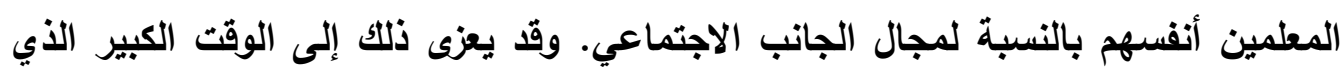
يقضيه المعلم في المدرسة مع الطلاب والمدرسين والإدارة من حيث عدد الساعات في اليوم

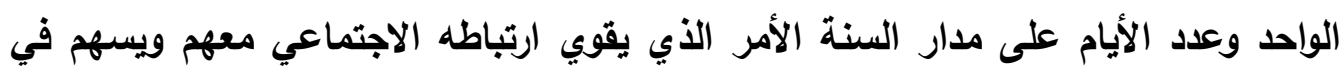
تكوين علاقات إيجابية بين عناصر المجتمع المدرسي الصغير والذي يتكون من المعلم

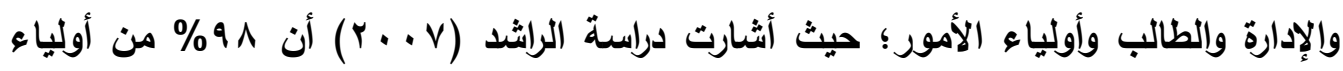
أمور الطلبة يحثون أبنائهم على احترام مدرسيهم. هذا بالإضافة إلى أن المكانة الاجتماعية

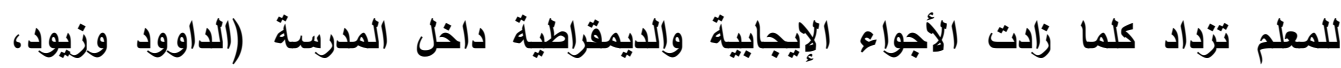

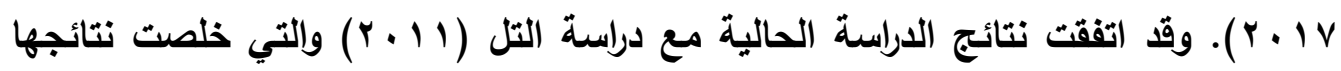
إلى حصول الجاتب الاجتماعي لمهنة التدريس على مكانة اجتماعية مرتفعة. وجاء مجال الأهمية والتقدير المجتمعي للمعلم في الرتبة الثانية، ويمتوسط حسابي

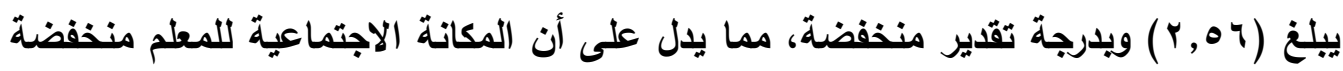

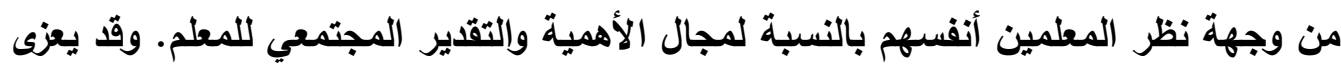
ذلك إلى تدني الصورة العامة للمعلم في المجتمع الكويتي وعدم حصوله على التقدير والاحترام

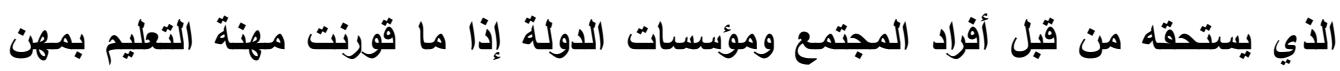


وتخصصات أخري. حيث أثنارت دراسة (Hall \& Langton, 2006) الي أن المعلم يحظى بمكانة اجتماعية مساوية للمكانة الاجتماعية للممرضين والصحافيين والمحاسبين وأقل من

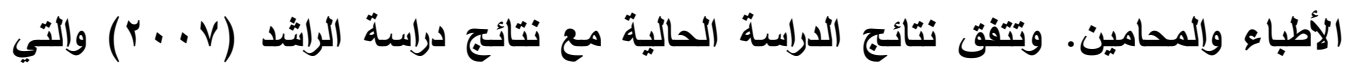
توصلت إلى أن Yr\% فقط من المطلمين يعتقاون أن المعلم يحظى باحترام أفراد المجتمع له.

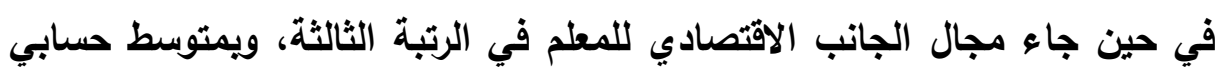

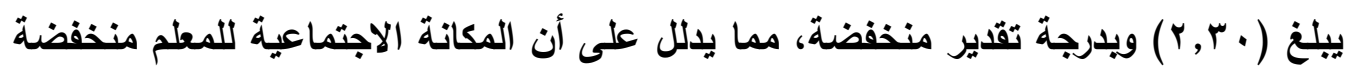

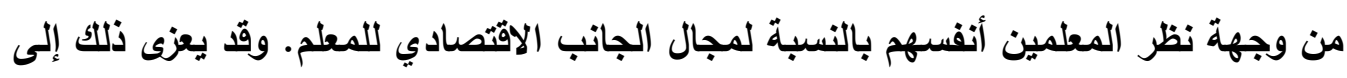

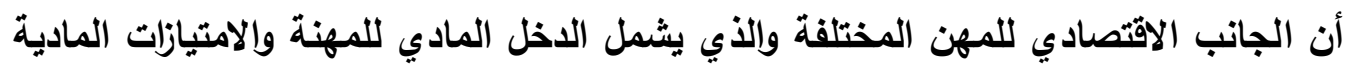

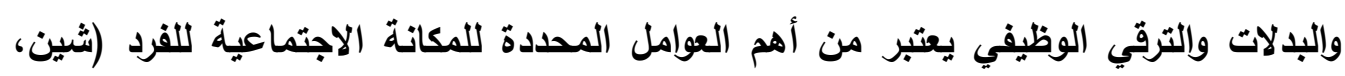

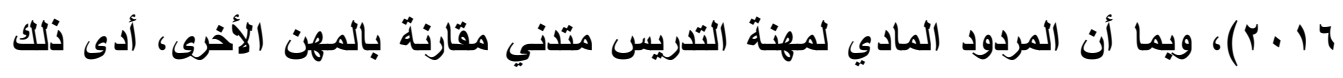

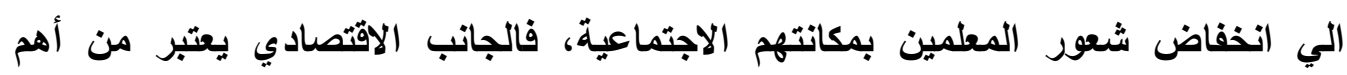

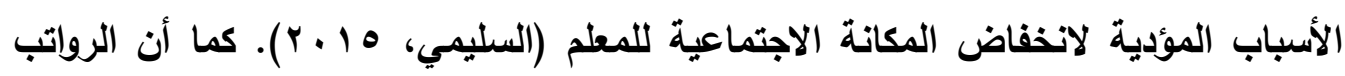

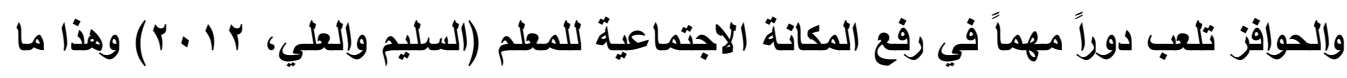

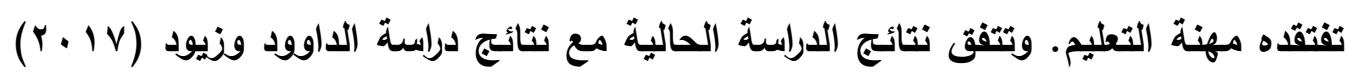
والتي توصلت الي انخفاض المكانة الاجتماعية للمعلم في جانبها الاقتصادي.

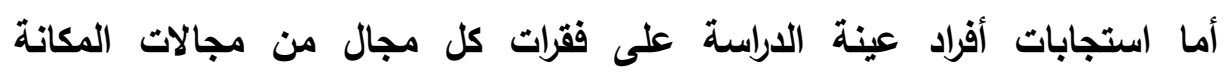

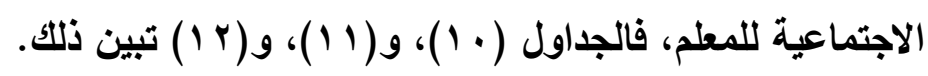




\section{واقع المكانة الاجتماعية للمعلم من وجهة نظر معلمي المرحلة الثانوية في محافظة العاصمة بدولة الكويت.}

جدول (· (1) المتوسطات الحسابية والاتحر افات المعيارية والرتبة ودرجة التقدير لمجال الجاتب الاقتصادي للمعلم

\begin{tabular}{|c|c|c|c|c|c|}
\hline التقدير & الترتيب & المعياري & المستوسط & الفقرات & رقامة \\
\hline متوسطة & 1 & 1,17 & Y,TY & يتجه الكثيرون لمهنة التعليم بسبب كثرة العطل & $\varepsilon$ \\
\hline منخفضة & $r$ & 1,14 & $r, O r$ & يضمن راتب المعلم الحياة الكريمة له & $\Lambda$ \\
\hline منخفضة & $r$ & $1, r q$ & $r, 01$ & اخترت مهنة التعليم بالرغم من توفر فرص & $\mathrm{V}$ \\
\hline منخفضة & $\varepsilon$ & 1,11 & Y,Y & أستطيع أن أدخر جز عاً من راتبي & $r$ \\
\hline منخفضة & 0 & $1,1 \mathrm{~V}$ & r, Yr & يتجه الكثيرون لمهنة التطليم بسبب الراتب & 7 \\
\hline منخفضة & 7 & $1, \cdot \varepsilon$ & r,19 & العمل كمعلم فقط كاف لسد حاجاتي الضرورية & 0 \\
\hline منخفضة & $\mathrm{V}$ & $1, \cdot v$ & $r, 0$ & تفوق الامتيازات المادية للمعلم الامتيازات المهرئ الاخرى & $r$ \\
\hline \multirow[t]{2}{*}{ منخفضة } & $\Lambda$ & $1,1 \cdot 1$ & $r, r$ & يتناسب راتب المعلم مع ما يبذله من جهر & 1 \\
\hline & & $\cdot, \mathrm{V} \otimes \mathrm{V}$ & $r, r$. & الجانب الاقتصادي للمعلم ككل & \\
\hline
\end{tabular}

يتبين من جدول (· (1) أن المتوسط الحسابي لاستجابات أفراد عينة الدراسة على لوانى

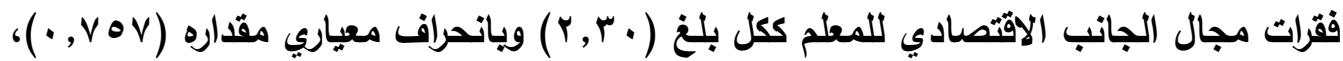
وقد تراوح المتوسط الحسابي لاستجابات أفراد عينة الدراسة على فقرات هذا المجال ما بين

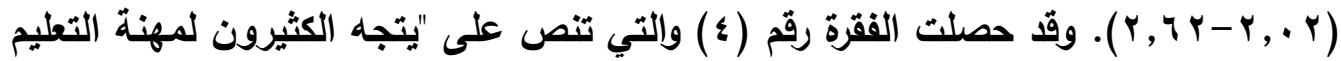
بسبب كثرة العطل" على أعلى متوسط حسابي (Y,Y,T) ويدرجة تقدير متوسطة، وقد تعزى هذه النتيجة الي انحصار المميزات الاقتصادية التي يحظى بها المعلم في الإجازات والعطل الكثيرة التي يحظى بها المعلم مقارنة بالمهن الأخرى. فيما حصلت الفقرة رقم (1) والتي تنص

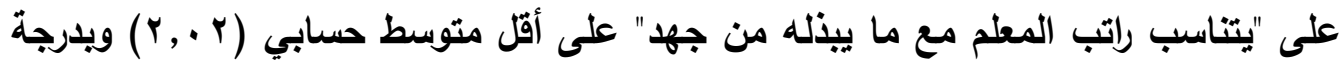
تقدير منخفضة، وتعكس هذه النتيجة الواقع الحالى للمعلم الأي يعاني من كثرة الأعباء الملقاة على عاتقه داخل وخارج الفصل، وضغوطات العمل العالية التي ترتبط بها مهنة التعليم والتي لا تتناسب بأي حال من الأحوال مع المقابل المادي الذي يتقاضاه. 


\section{واقع المكانة الاجتماعية للمعلم من وجهة نظر معلمي المرحلة الثانوية في محافظة العاصمة بدولة الكويت.}

جدول (1 1 ) المتوسطات الحسابية والانحر افات المعيارية والرتبة ودرجة التقدير لمجال الجاتب الاجتماعي للمعلم

\begin{tabular}{|c|c|c|c|c|c|}
\hline التقاجير & الترتيب & المعياري & المستوسط & الفقرات & رقفرة \\
\hline مرتفعة & 1 & $\cdot, 9 \wedge$ & $r, \wedge \uparrow$ & أحظى بعلاقات جيدة مع زملائي في العمل & 1. \\
\hline مرتفعة & $r$ & $\cdot, 97$ & $r, T V$ & يتحدث معي أولياء الأمور بطريقة تلال على التقير & $r$. \\
\hline مرتفعة & $r$ & $\cdot 90$ & $r, 74$ & ينظر لي الطلاب باعتباري قدوة حسنة لهم & ri \\
\hline مرتفعة & $\varepsilon$ & $1, \cdot 1$ & $r, \diamond \wedge$ & يحترم أولياء الأمور ملاحظاتي بخصوص & ir \\
\hline مرتفعة & 0 & $1, \cdot 1$ & $r, 00$ & أشعر بتقلير أولياء الأمور لاوري كمعلم & 17 \\
\hline مرتفعة & 0 & 1,14 & $r, 00$ & أشعر باحترام الطلاب خارج الفصل & 11 \\
\hline مرتفعة & $\mathrm{V}$ & 1,11 & $r, 0 \leq$ & أشعر باحترام الطلاب خارج المدرسة & Ir \\
\hline مرتفعة & $\Lambda$ & 1,1 & $r, \varepsilon \varepsilon$ & أشعر بتقدير أولياء الأمور لاوري كمعلم & 17 \\
\hline متوسطة & 9 & $1, \cdot v$ & $r, r r$ & يستشيرني الطلاب في مشاكلهم الخاصة & 11 \\
\hline متوسطة & $1 \cdot$ & $1, \cdot 7$ & $r, r \mu$ & تأخذ الإدارة المدرسية بآرائي التربوية & IV \\
\hline متوسطة & 11 & $1, \cdot \varepsilon$ & $r, r$ & الاجتمل كمعلم يتيح لي القيام بواجباتية الاجنياتي & $1 \varepsilon$ \\
\hline متوسطة & Ir & $1,1 \mathrm{~V}$ & $r$ & يتيح لي العمل كمعلم قضاء وقت مناسب أسرتي & 9 \\
\hline متوسطة & ir & 1,11 & r, Vo & العمل كمعلم يوفر لَي وقت مناسب لممارسة & 19 \\
\hline مرتفعة & & $\cdot, T \vee \mu$ & $r, \varepsilon$. & الجاتب الاجتماعي للمعلم ككل & \\
\hline
\end{tabular}

يتبين من جدول (1 1) أن المتوسط الحسابي لاستجابات أفراد عينة الدراسة على العلى

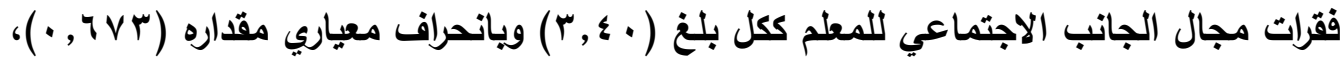
وقد تراوح المتوسط الحسابي لاستجابات أفراد عينة الدراسة على فقرات هذا المجال ما بين

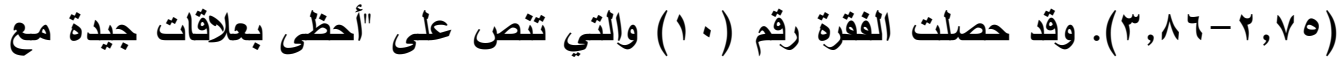

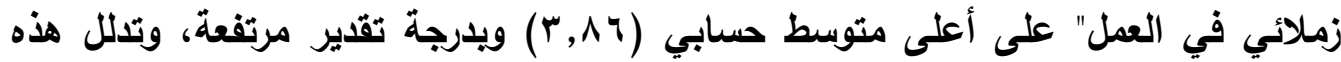
النتيجة على المناخ الإيجابي الذي يحظى به المعلم في مجتمعه المدرسي الصغير ويين عناصر هذا المجتمع. فيما حصلت الفقرة رقم (9 1 ) والتي تنص على "العمل كمعلم يوفر لي وقت مناسب لممارسة هواياتي" على أدنى متوسط حسابي (Y,V0) ويدرجة تقدير متوسطة، وقد يعود السبب في ذلك إلى الأعباء الكثيرة للمهنة والتي قد تتطلب من المعلم العمل خارج 
أوقات الدوام الرسمي وخارج أسوار المدرسة، في المنزل مثّلا، الأمر الذي قد لا يتيح له تخصيص جزءا من وقته لممارسة هواياته وأنشطته المختلفة.

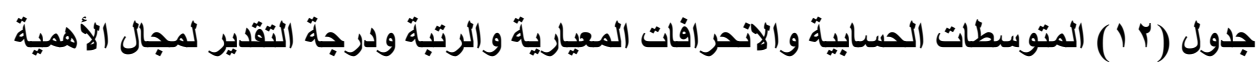
و التقدير المجتمعي للمعلم المعات

\begin{tabular}{|c|c|c|c|c|c|}
\hline التقاجير & الترتيب & المعياري & المستوسط & الفقرات & الفقرة \\
\hline متوسطة & 1 & $1,1 \mathrm{~V}$ & $r, q V$ & يتفاخر المعلم بمهنته في المجالس & $r \varepsilon$ \\
\hline متوسطة & $r$ & 1,10 & $r, 90$ & يحظى المعلم باحترام وتقدير افراد & ro \\
\hline متوسطة & $r$ & 1,11 & $r, \wedge q$ & ينظر أفراد المجتمع للمعلم باعتباره أداة & YT \\
\hline متوسطة & $\varepsilon$ & 1,1 & $r, V V$ & يحظى المعلم بثقة أفراد المجتمع & $r \varepsilon$ \\
\hline متوسطة & 0 & 1,11 & r,Vo & لحترام أفراد المجتمع المهن المعلم مثل & rr \\
\hline متوسطة & 7 & 1,97 & Y,VY & 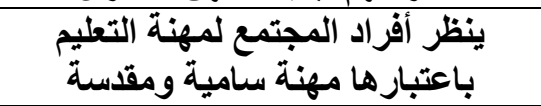 & $r \wedge$ \\
\hline متوسطة & $\mathrm{V}$ & 1,14 & $r, 79$ & يحظى المعلم بتحفيز أفراد المجتمع له & ry \\
\hline متوسطة & $\Lambda$ & $1,1$. & $r, 71$ & ينظر لي الموظف الحكومي نظرة تقدير ئلم بأني معلم & rq \\
\hline منخفضة & 9 & $\cdot 9 \wedge$ & $Y, \leqslant 7$ & يتم الحديث عن المعلم بثكل جيد في الخاصة & ro \\
\hline منخفضة & 1. & $\cdot, 9 \varepsilon$ & $r, r \wedge$ & الصورة العامة للمعلم في وسائل & rV \\
\hline منخفضة & 11 & $1,+r$ & Y,YT & يتناول الإعلام قضاية المعلم بصورة & $r \mu$ \\
\hline منخفضة & Ir & 1,11 & Y,YY & تثجع الأسر أبنائها للانخر اط في مهنة & $r$ \\
\hline منخفضة & Ir & $1, \cdot 1$ & Y,YY & 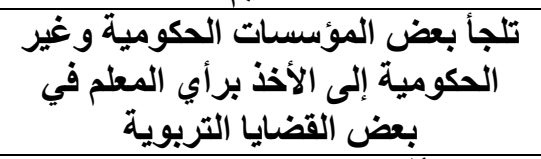 & rr \\
\hline منخفضة & $1 \varepsilon$ & $1, \cdot 1$ & $r$ & ينظر أفراد المجتمع للمعلم كنظرتهم والمهند & $r$ \\
\hline منخفضة & & $\cdot, \vee \otimes \wedge$ & $r, 0 Y$ & جاتب الأهمية والتقدير المجتمعي للمعلم & \\
\hline
\end{tabular}

يتبين من جدول (Y I) أن المتوسط الحسابي لاستجابات أفراد عينة الدراسة على

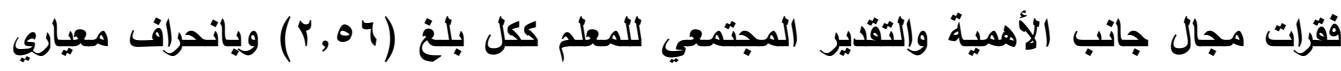


مقداره (TVT , · )، وقد تراوح المتوسط الحسابي لاستجابات أفراد عينة الدراسة على فقرات هذا

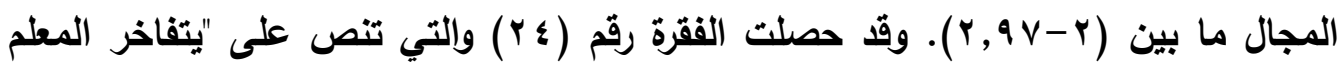

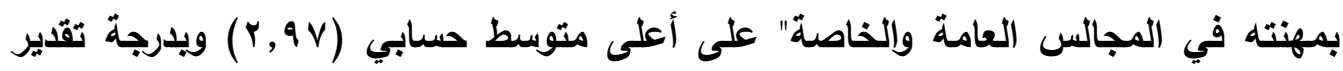
متوسطة، وتؤكد هذه النتيجة على أن المعلم لايزال مؤمناً بأهمية الدور المناط به على على الرغم

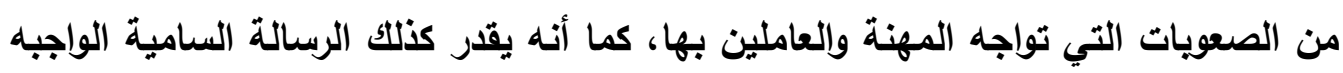

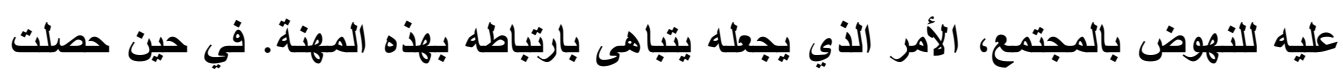

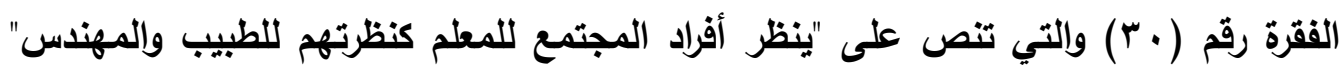

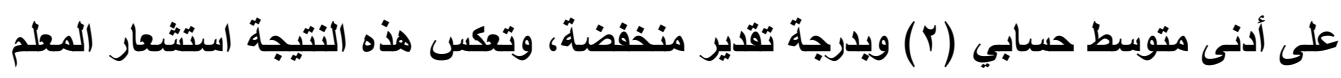

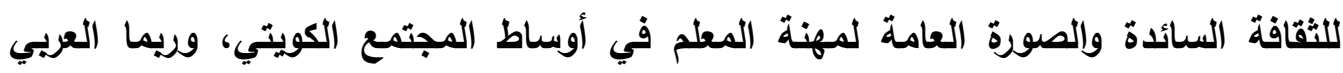

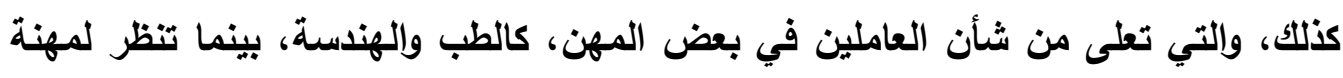

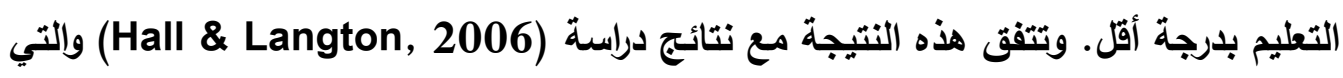
أظهرت نتائجها أن الأطباء يتمتعون بمكانة اجتماعية أعلى من المعلمين. للإجابة عن السؤال الثاني: هل توجد فروق ذاءت ذات دلائة إحصائية في المكانة الاجتماعية

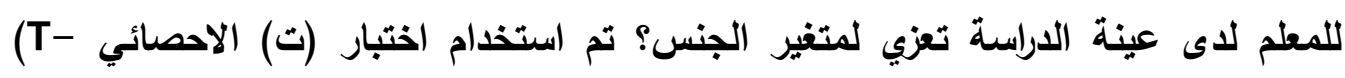

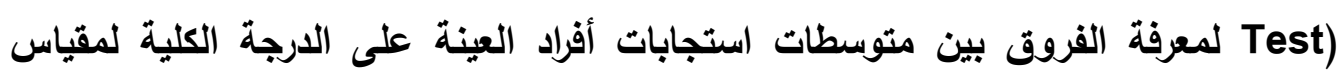

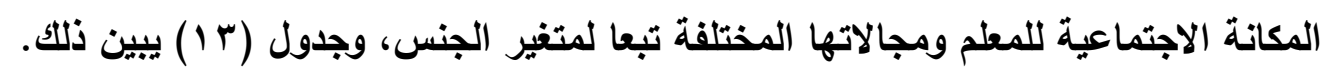


جدول (ب ا ) المتوسطات الحسابية والاتحر افات المعيارية واختبار (ت) الإحصائي لمعرفة الفروق بين الإين

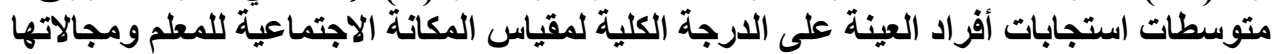

\begin{tabular}{|c|c|c|c|c|c|c|}
\hline \multirow{2}{*}{\multicolumn{7}{|c|}{ 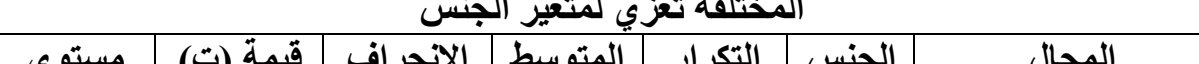 }} \\
\hline مستوى & & & & & & المجال \\
\hline الالالة الالة & 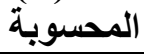 & المعياري & الحسابي & & & \\
\hline \multirow[t]{2}{*}{$*,, 1 \leq$} & \multirow[t]{2}{*}{$Y, \leqslant 9 q$} & $\cdot, \vee \vee 9$ & $r, I V$ & $1 \cdot v$ & ذكر & \multirow{2}{*}{ الجانب الاقتصادي } \\
\hline & & $\cdot, \mathrm{V} \leqslant \mathrm{Y}$ & Y,\&1 & 119 & أنثي & \\
\hline \multirow[t]{2}{*}{$\cdot, 79 r$} & \multirow[t]{2}{*}{$\cdot, \leqslant \mu \wedge$} & $\cdot, v \backslash 1$ & $r, r v$ & $1 . v$ & ذكر & \multirow{2}{*}{ الجانب الاجتماعي } \\
\hline & & $\cdot, 7 \leq$ & $r, \& 1$ & 119 & أنثي & \\
\hline \multirow[t]{2}{*}{$* \cdot, \cdot 1}$. & \multirow[t]{2}{*}{ Y,YI. } & $\cdot, \mathrm{V} \leqslant 1$ & $Y, \& Y$ & $1 \cdot v$ & ذكر & \multirow{2}{*}{ والتقدير المجتمعية الأهمية } \\
\hline & & $\cdot, \mathrm{v} \otimes 0$ & $r, 7 \Lambda$ & 119 & أنثي & \\
\hline \multirow[t]{2}{*}{$* \cdot, \cdot M$} & \multirow[t]{2}{*}{$r, I V V$} & $\cdot, 71 \leq$ & $r, V Y$ & $1 \cdot v$ & ذكر & \multirow[t]{2}{*}{ الارجة الكلية } \\
\hline & & $\cdot, 09 \leqslant$ & $r, \wedge q$ & 119 & أنثي & \\
\hline
\end{tabular}

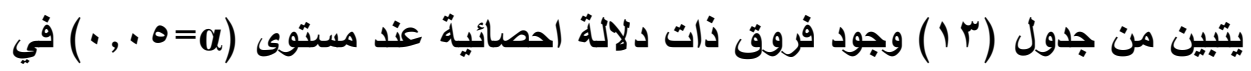
استجابات معلمي المرحلة الثانوية في محافظة العاصمة في دولة الكويت حول المكانة الاجتماعية للمعلم وذلك في مجال الجانب الاقتصادي للمعلم، ومجال الأهمية والتقدير المجتمعي للمعلم، والدرجة الكلية للأداة، تبعاً لمتغير الجنس؛ حيث بلغت قيمة (ت) المحسوية

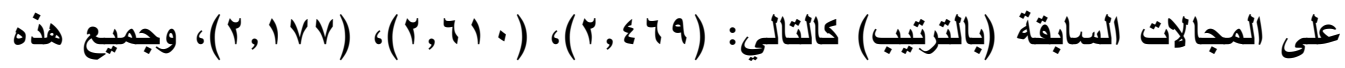

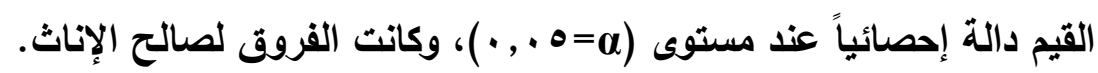
وقد يعزى وجود فروق ذات دلالة إحصائية في مجال الجانب الاقتصادي للمعلم لاى إه أفراد عينة الاراسة تبعا لمتغير الجنس، لصالح الإناث، إلى كثرة الأعباء والالتزامات المالية التي يضطلع بها المعلمون الأكور في مقابل قثة تلك الالتزامات لاى المعلمات، فالثقافة العربية والإسلامية تفرض على الرجل في المقام الأول أن يتحمل جميع الأعباء المالية

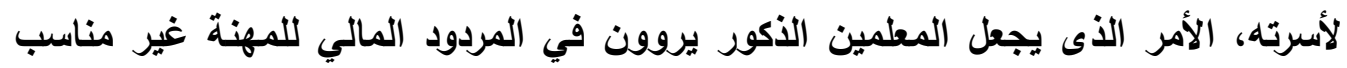
لسد احتياجاتهم وإحتياجات أسرهم، خصوصاً إذا ما علمنا أن الراتب الشهري للمعلمين الذكور والإناث متساوٍ. وقد اتفقت نتائج الدراسة الحالية مع نتائج دراسة الداوود وزيود (Y (Y) والتي أظهرت نتائجها وجود فروق ذات دلالة إحصائية في مجال الجانب الاقتصادي للمكانة الاجتماعية للمعلم لاى المعلمين تبعاً لمتغير الجنس، لصالح الإناث. 
أما بالنسبة لمجال الأهمية والتقدير المجتمعي للمعلم، فقد تعزى الفروق ذات الدالاية

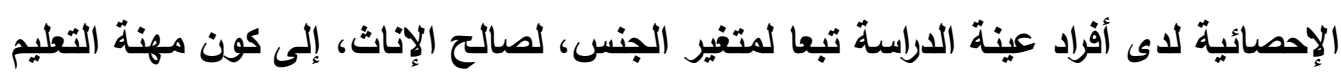

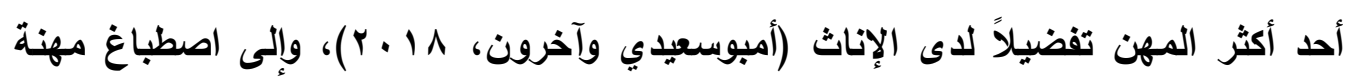

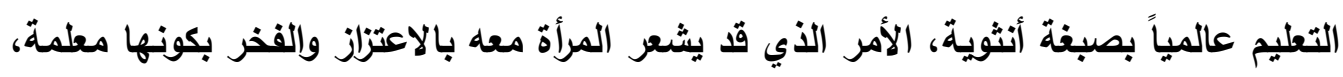

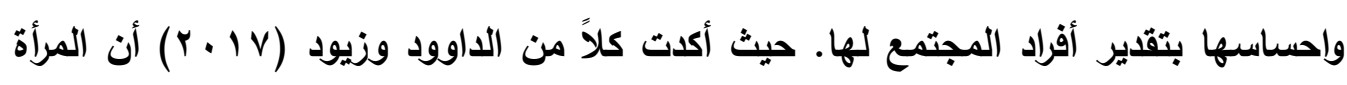

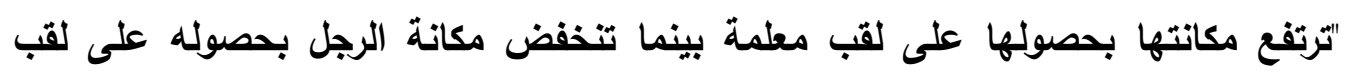

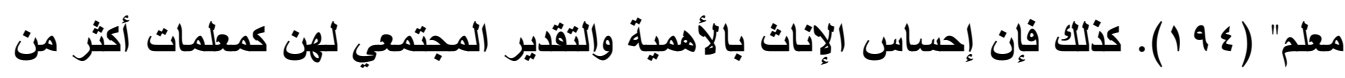

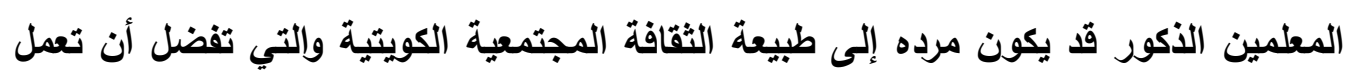
المرأة في الوظائف التي لا تسمح بيئة العمل بها من الاختلاط بين الجنسين كما هو الحال

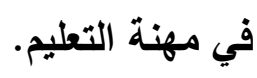

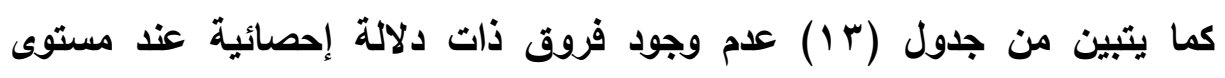

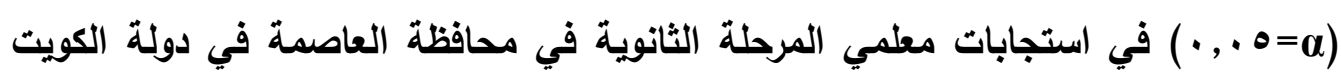

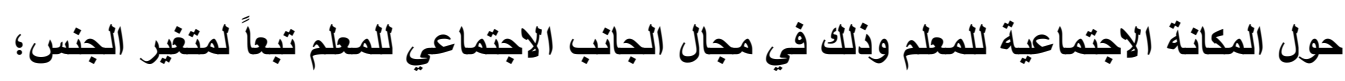

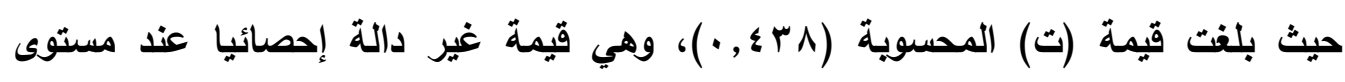

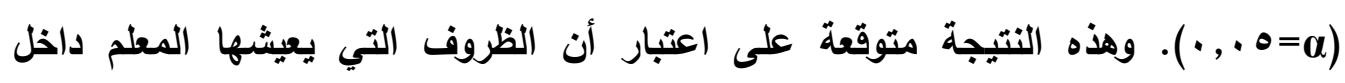

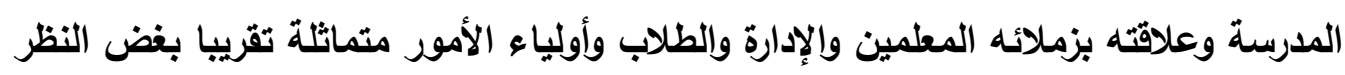

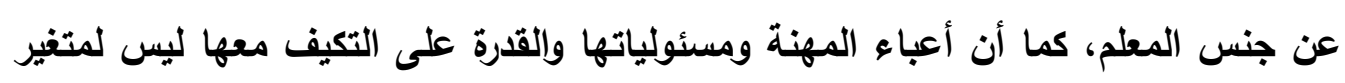

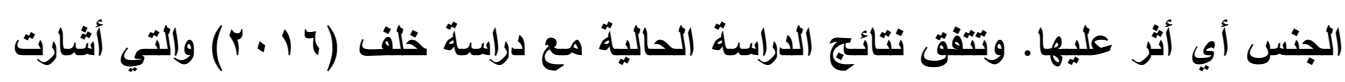

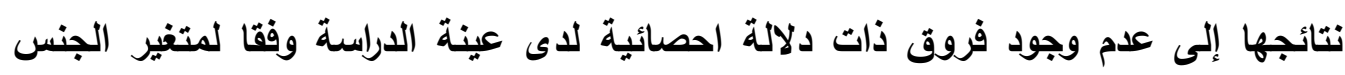

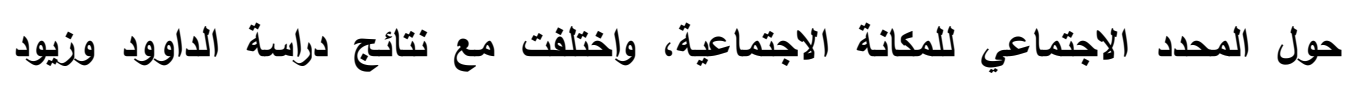

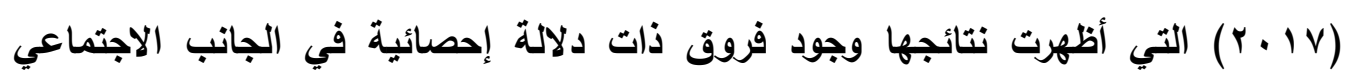

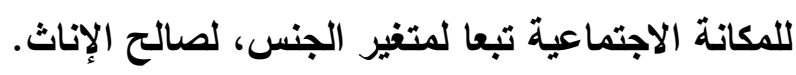

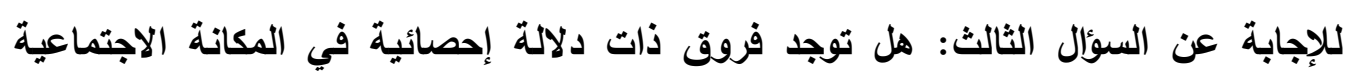

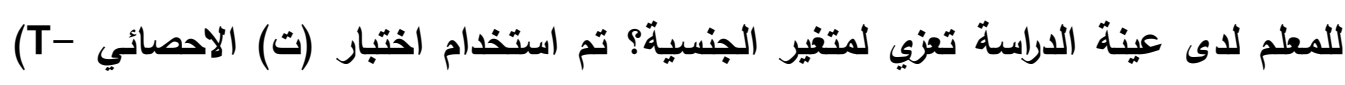
لمعرفة الفروق بين متوسطات استجابات أفراد عينة الدراسة على الارجة الكلية 
لمقياس المكانة الاجتماعية للمعلم وأبعادها المختلفة تبعا لمتغير الجنسية، وجدول (؛ ا) يبين ذللك.

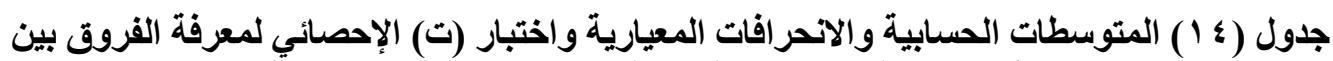

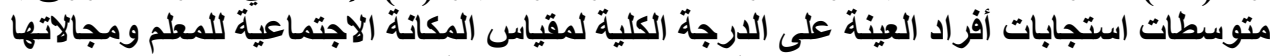

\begin{tabular}{|c|c|c|c|c|c|c|}
\hline \multicolumn{7}{|c|}{ المختلفة تعزي لمتغير الجنسية } \\
\hline مستوي & قيمة (ت) & الانحراف & المتوسط & التكرار & الجنسية & المجال \\
\hline الالالة & المحسوبة & المعياري & الحسابي & & & \\
\hline \multirow[t]{2}{*}{$*, \cdots$} & \multirow[t]{2}{*}{$\wedge, \uparrow \wedge \varepsilon$} & $\cdot, \sqrt{ }, \varepsilon \varepsilon$ & r, vo & 94 & كويتي & \multirow{2}{*}{ الجاتب الاقتصادي } \\
\hline & & •, OV. & 1,91 & Irt & كويتي & \\
\hline \multirow{2}{*}{$*, \cdots$} & \multirow[t]{2}{*}{$r, v \leqslant 0$} & $\cdot, 79 \mathrm{~V}$ & $r, 09$ & 94 & كويتي & \multirow{2}{*}{ الجاتب الاجتماعي } \\
\hline & & 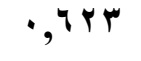 & $r, Y \uparrow$ & Trt & غير & \\
\hline \multirow[t]{2}{*}{$* \cdot, \cdots$} & \multirow[t]{2}{*}{ r, rar } & $\cdot, \wedge \cdot 9$ & $r, v^{r}$ & 94 & كويثي & \multirow{2}{*}{ المجتمعي التقليريلم الأهمية } \\
\hline & & $\cdot, 7 \wedge 9$ & $r, \xi r$ & 1Tr & كويتيّ & \\
\hline \multirow[t]{2}{*}{$*, \cdots$} & \multirow[t]{2}{*}{$0, Y \leqslant Y$} & $\cdot 749$ & $r, 4$ & 94 & كويتي & \multirow[t]{2}{*}{ الارجة الكلية } \\
\hline & &., $01 \mathrm{~V}$ & זיר,ץ & Irt & كويتي & \\
\hline
\end{tabular}

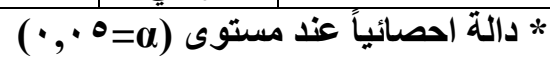

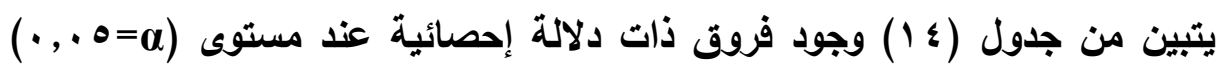

في استجابات مطلمي المرحلة الثانوية في محافظة العاصمة في دولة الكويت حول المكانة الاجتماعية للمعلم وذلك في جميع المجالات (الجانب الاقتصادي، والجانب الاجتماعي، وجاتب

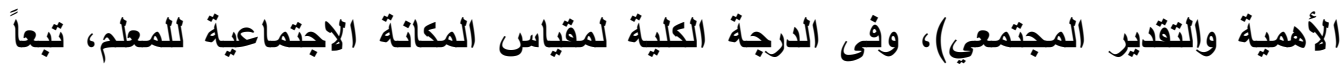

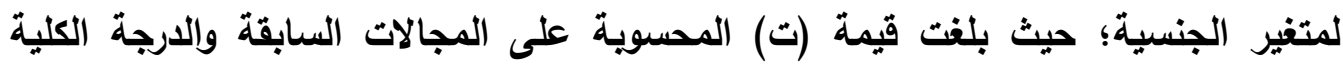

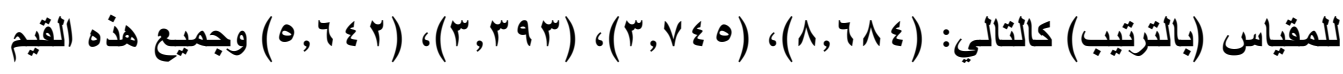

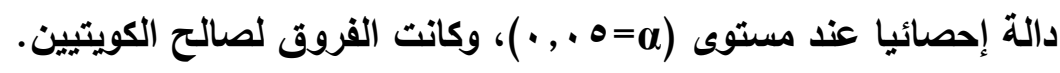
وقد يعود السبب في وجود فروق ذات دلالة إحصائية في مجال الجاتب الاقتصادي

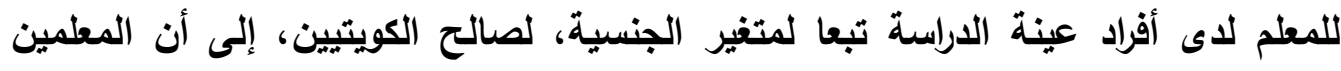
الكويتيين يتمتعون برواتب شهرية وامتيازات مالية ومكافآت سنوية تفوق تلك التي يحصل عليها نظرائهم الغير كويتيين. كما أن فرص الترقي المهني وما يصاحبها من امتيازات مالية 
تكون الأولوية فيها للكويتيين الأمر الذي من شأنه أن يخفض من تقديرات المعلمين غير

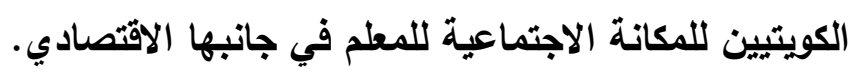

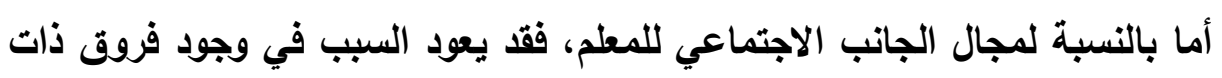

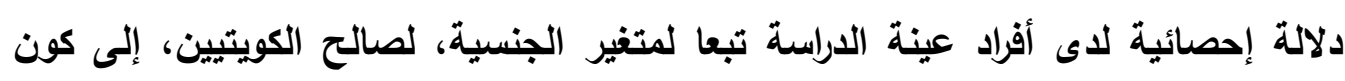

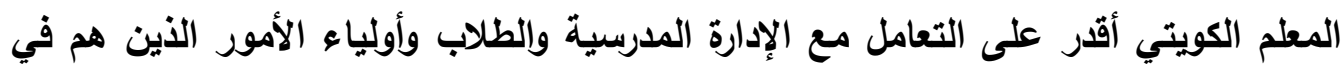

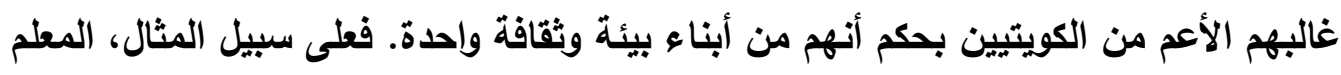

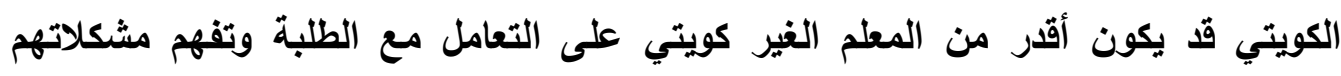

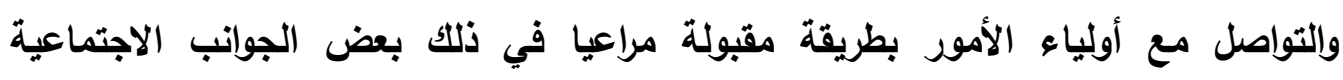

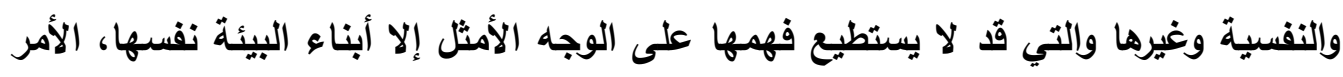

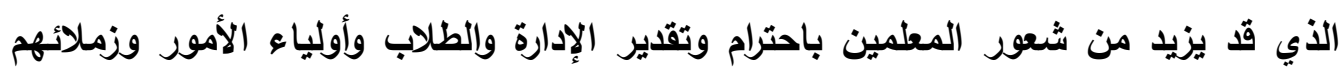

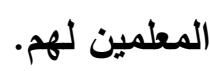

كما أن إحساس المعلمين الكويتيين بمكانة اجتماعية تفوق ما لاي نظرائهم من غير الإني

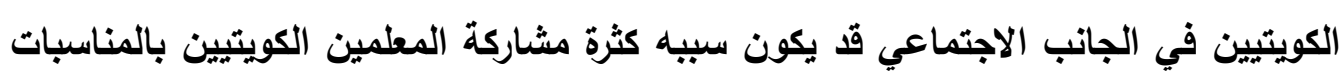

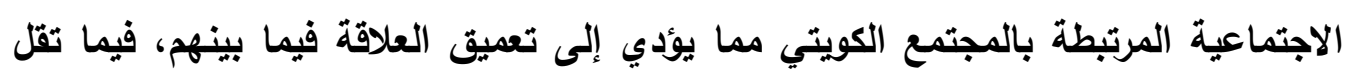

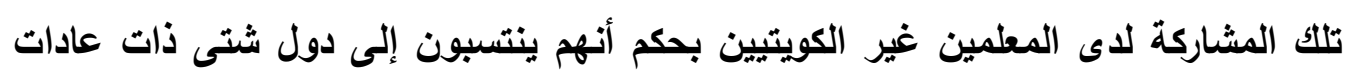

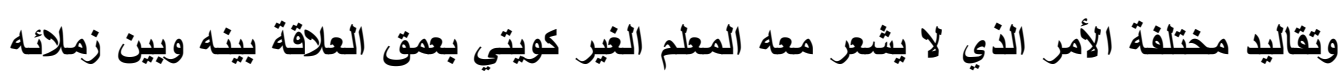

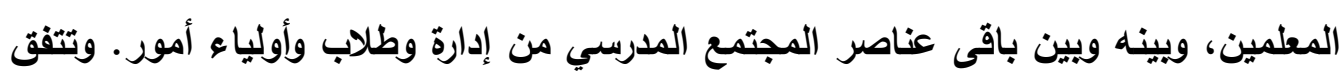

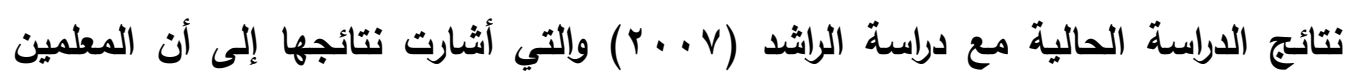

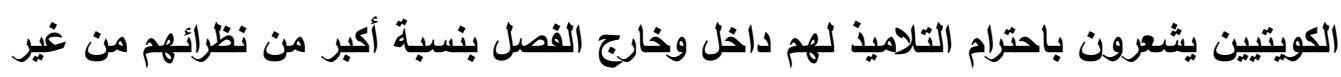
الكويتيين. وقد يعود السبب في وجود فروق ذات دلالة إحصائية في مجال الأهمية والتقدير

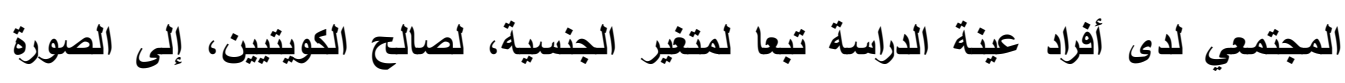

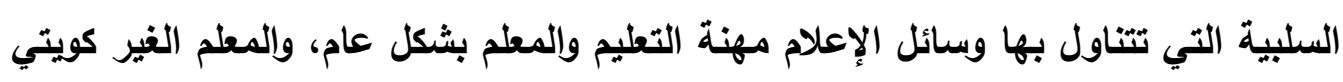

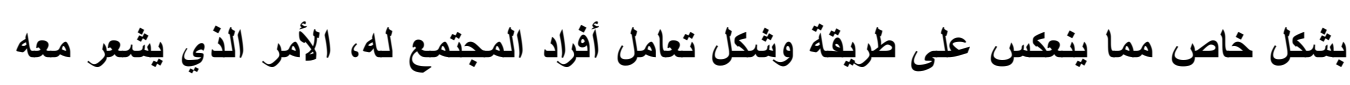

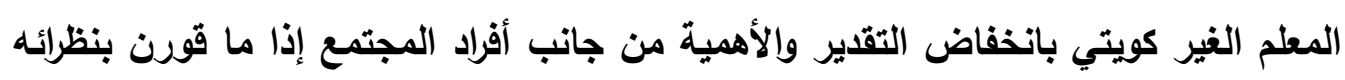
من المطمين الكويتيين. 
للإجابة عن السؤال الرابع: هل توجد فروق ذات دلالة إحصائية في المكانة

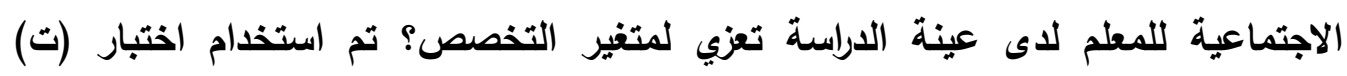

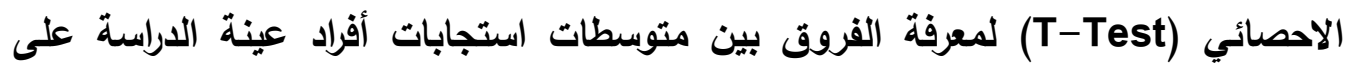

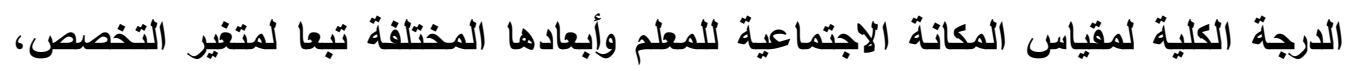
وجدول (10) يبين ذلك.

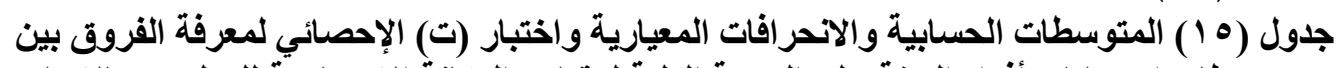

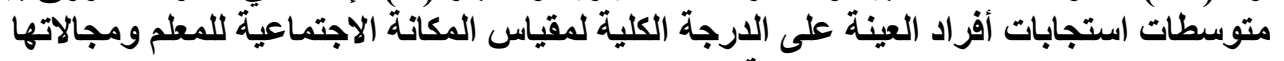

\begin{tabular}{|c|c|c|c|c|c|c|}
\hline اللالادة & قالمسمة (ت) & المعياري & الكستوسي & التكرار & التخصص & البعد \\
\hline \multirow[t]{2}{*}{$\cdot, \mathrm{V} \uparrow \wedge$} & \multirow[t]{2}{*}{ • } & $\cdot$, AYA & $r, Y V$ & QY & تغصصية & \multirow{2}{*}{ اللاقتصادي } \\
\hline & & $\cdot, v \cdot v$ & $r, r \mid$ & $1 T \varepsilon$ & تخصصاتية & \\
\hline \multirow[t]{2}{*}{ - ,9ro } & \multirow[t]{2}{*}{$\cdot, 99$} & A & $r, \varepsilon$. & 94 & تخصصية & \multirow{2}{*}{ الاجتماعي } \\
\hline & & $\cdot$, , & $r, r q$ & $1 T \xi$ & تخصصات انسانية & \\
\hline \multirow[t]{2}{*}{$\cdot, 091$} & \multirow[t]{2}{*}{ •, OrV } & , $7 \times 9$ & $r, \bullet q$ & QY & تغصصية & \multirow{2}{*}{ جانب الأهمية } \\
\hline & & $\cdot, \wedge \cdot q$ & $r, 04$ & $1 \pi \varepsilon$ & تخصصاتية & \\
\hline \multirow[t]{2}{*}{ •, ^ } & \multirow[t]{2}{*}{$\cdot, r+q$} & ., & $r, \wedge r$ & QY & تخصية تلمات & \multirow{2}{*}{ الدرجة الكلية } \\
\hline & & $\cdot, 7 \leqslant 1$ & $r, \wedge$. & $1 T \xi$ & تخصصاتية & \\
\hline
\end{tabular}

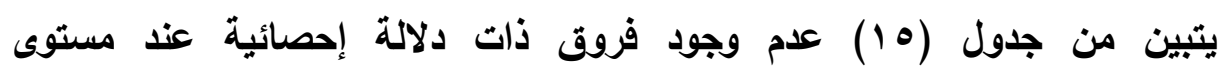

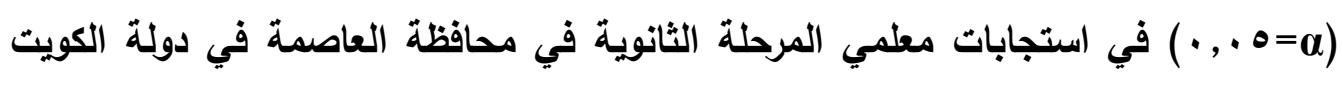

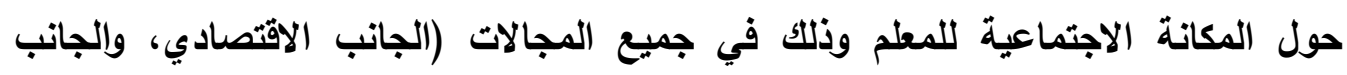

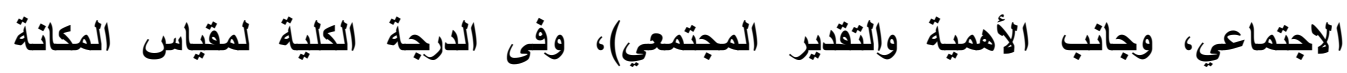

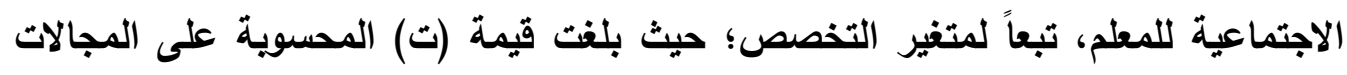

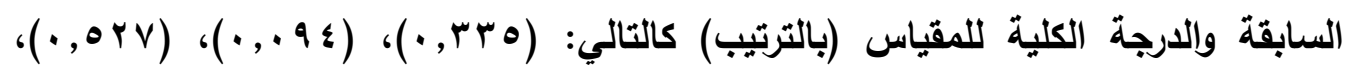

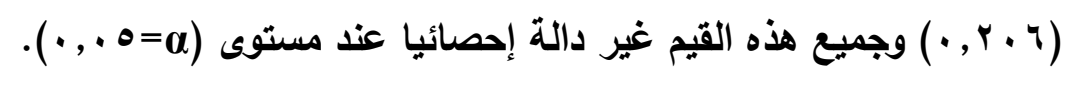


بالنسبة لمجال الجاتب الاقتصادي للمكانة الاجتماعية للمعلم، فقد يعزى علدم وجود

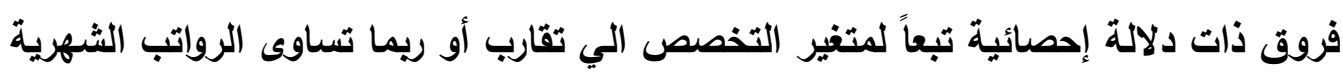

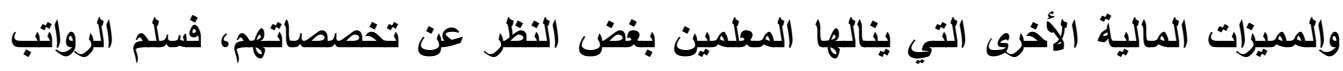

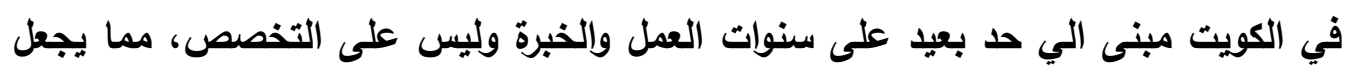

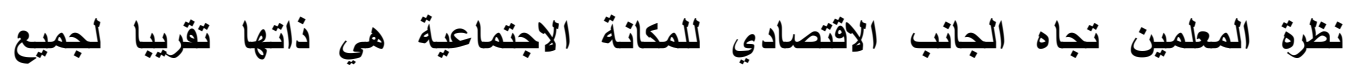

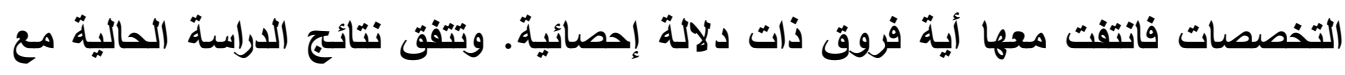

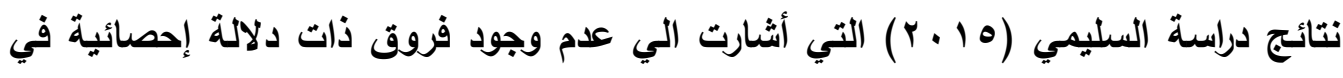

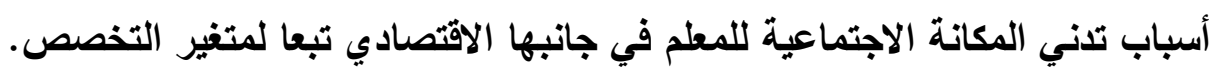

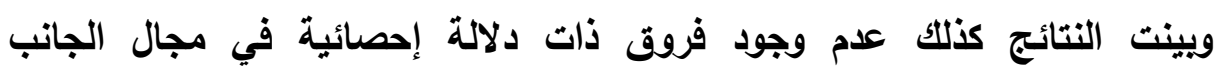

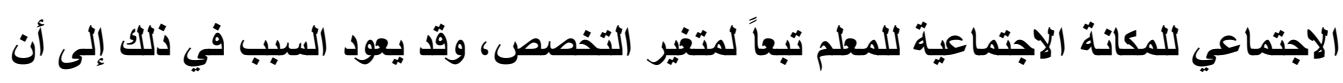

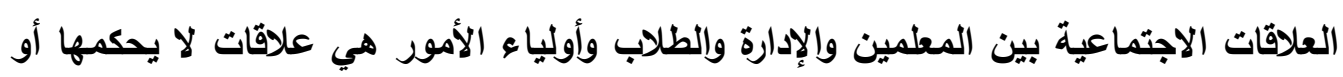

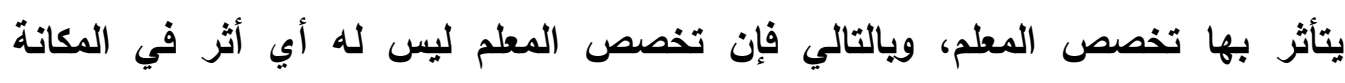

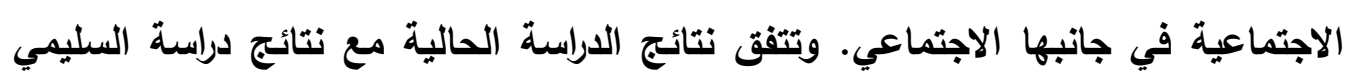

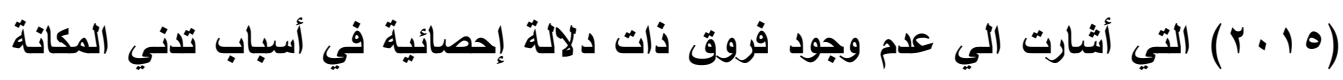

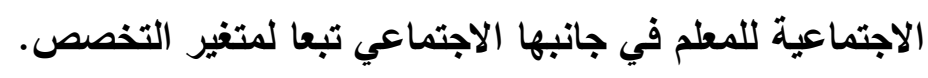

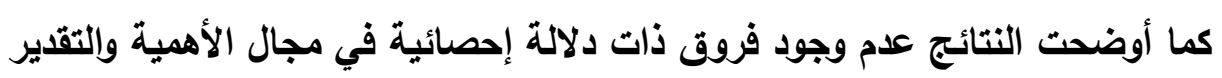

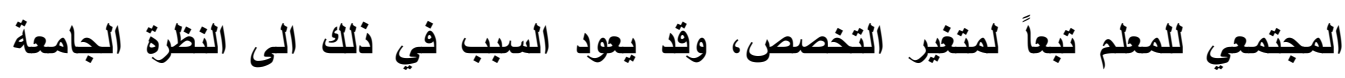

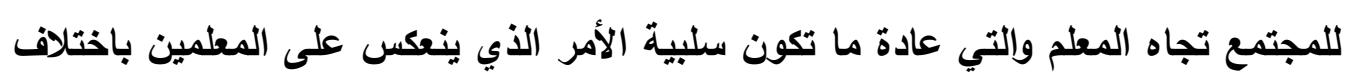
تخصصاتهم فيتكون لايهم نفس التصور والاعتقاد تجاه أهميتهم في المجتمع.

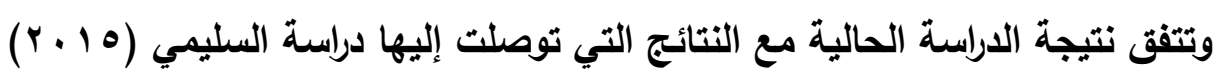

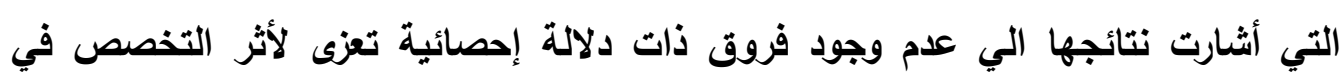

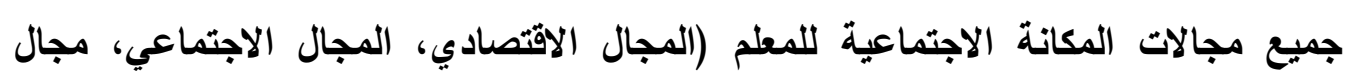

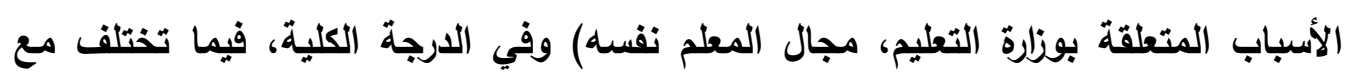

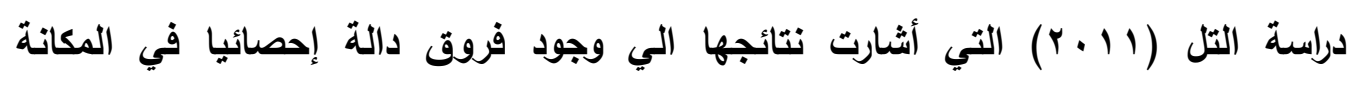
الاجتماعية للمطلم تعزى لمتغير التخصص لصالح ذوي التخصصات الإنسانية والأدبية. 


\section{التوصيات}

في ضوء النتائج السابقة، توصي الاراسة بالآتي:

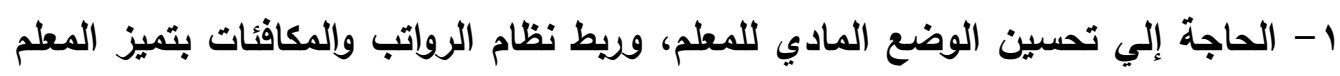

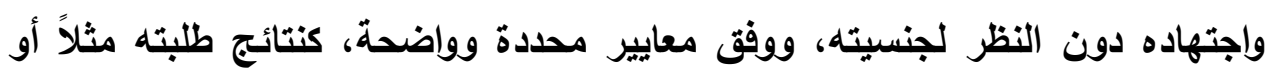

$$
\text { الدورات التي يجتازها. }
$$

r- العمل على تحسين بيئة العمل المدرسي لزيادة الاتجاهات الإيجابية للمعلمين تجاه مهنتهم مما يسهم في زيادة الفاعلية الإنتاجية. r- العمل على إثراك المطلمين في صياغة القرارات التريوية فهم الأقدر على استكثاف المشكلات ووضع تصورات لحلها. ع - ضرورة وضع تشريعات ترتقي بمكانة المعلم وتحفظ له حقوقه أسوة بالمهن الأخرى ذات التهات

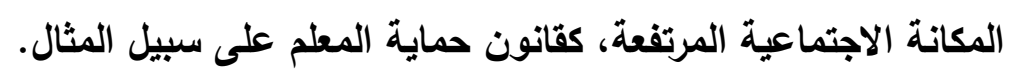

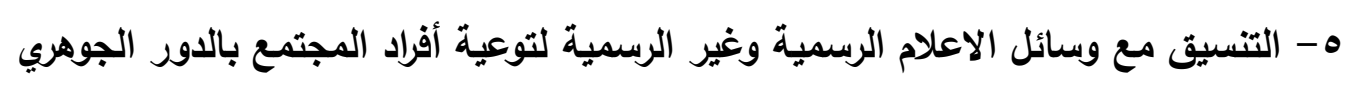
الأي يقوم به المعلم في نماء وتطور المجتمع.

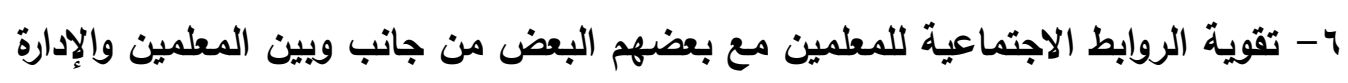

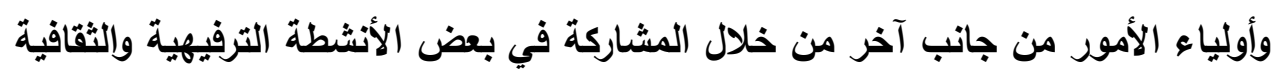

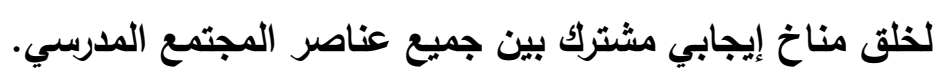

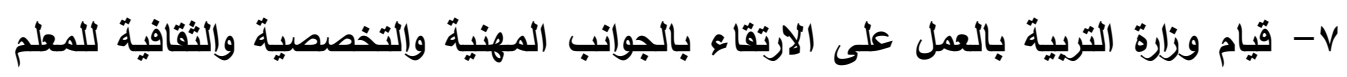

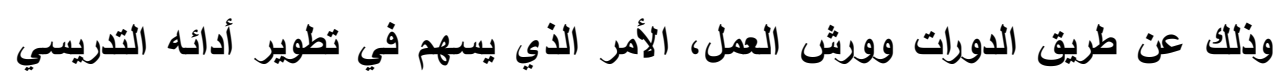
وتغيير النظرة السلبية تجاهه. 


\section{المراجع}

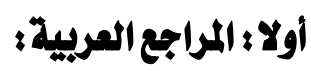

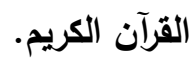

(بن ماجه، محمد بم يزيد. (ب.ت). سنن ابن ماجه، تحقيق - محمد فؤاد عبد الباقي، بيروت:

دار الفكر.

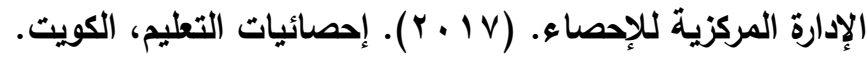

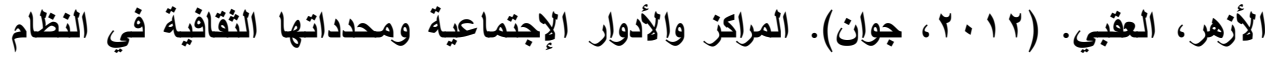

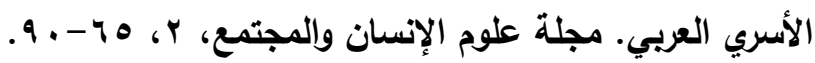

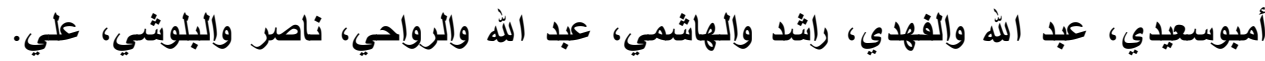

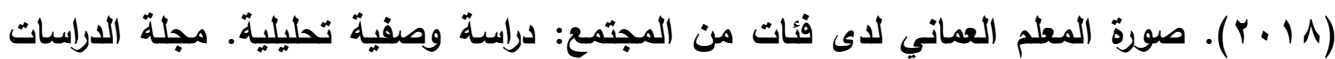

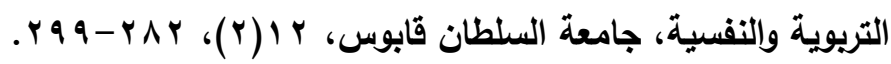

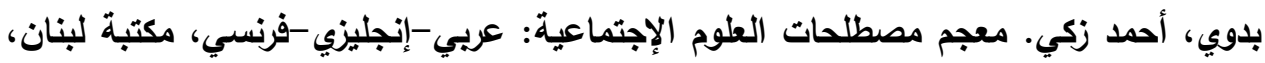

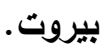

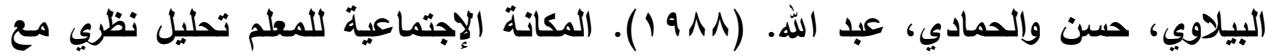
إلقاء الضوء على مكانة المعلم في دولة قطر. دراسات في بعض القضائ القضايا التريوية، مركز البحوث التزيوية، جامعة قطر ، المجلد العشرون.

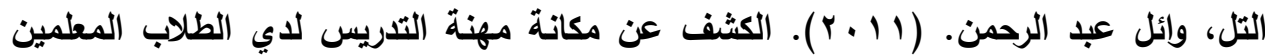
الخريجين في جامعة جازان بالمملكة العربية السعودية والعوامل المؤئرة فيها. المجلة التريوية، جامعة الكائة

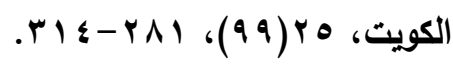

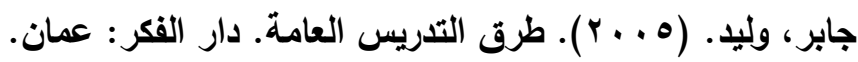

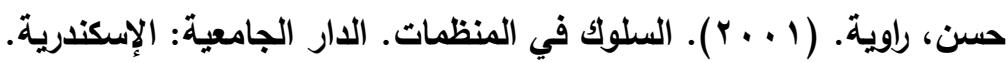

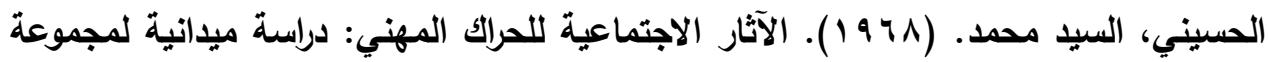

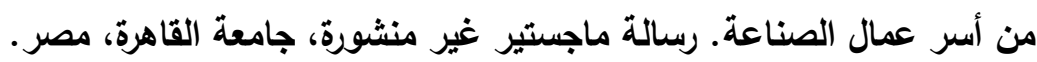

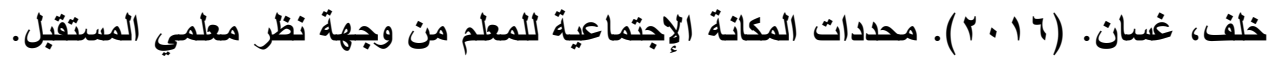

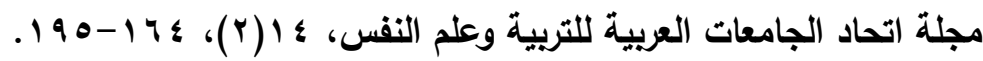

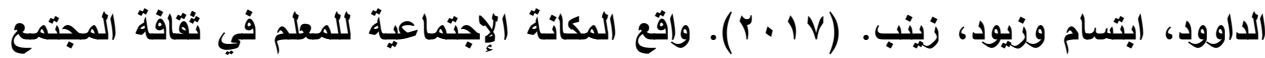
السوري من وجهة نظر المعلمين أنفسه (دراسة ميدانية في مدينة الحسكة). مجلة جامعة البعث، . r. O-179، (79) r9 


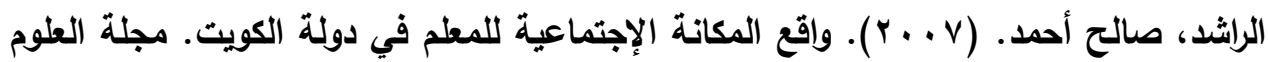

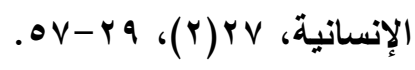

السبعاوي، فضيلة. ظاهزة الغش في الامتحانات المدرسية لاى طلبة المرحلة الإعدادية أسبابها

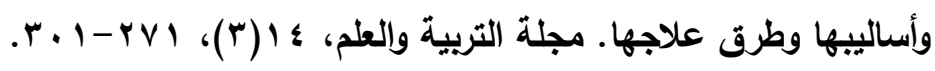

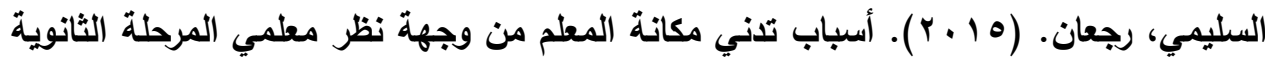
بمدينة حائل. رسالة ماجستير غير منشورة، جامعة أم القري، المملكة العربية السعودية.

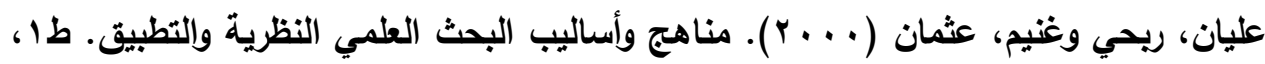
دار صفاء للنشرو التوزيع، عمان.

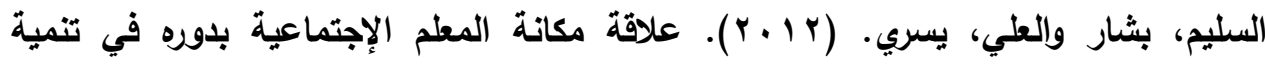
المجتمع كما يقرها معلموا المدارس الثانوية في الأردن. مجلة الجامعة الإسلامية للاراسات التربوية

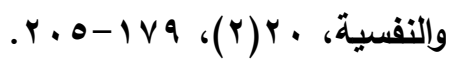

شين، سعيدة. (Y (Y (Y). التصورات الاجتماعية للعوامل المحددة لمكانة المعلم في المجتمع: دراسة ميدانية على عينة من معلمي الطور الابتدائي بمدينة بسكرة. مجلة العلوم الإنسانية، ع ؟Y (Y)، . $1 \leqslant \leqslant-1$.

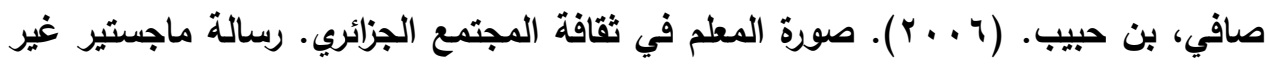
منشورة، جامعة أبي بكر بلقايد، الجزائر.

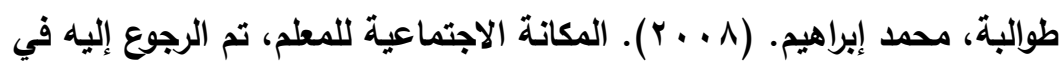
http://tawalbehmib.blogspot.com/2008/06/blog-post_04.html عبد الحسين، بشري. (11 +r). المكانة الإجتماعية لادي تدريسي جامعة بذاد. مجلة العلوم

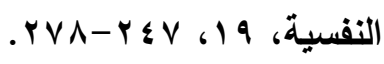
العبودي، ستار. (997 (9 ). البحث عن المكانة النفسية والإجتماعية وعلاقته بيعض المتغيرات لاي الموظفين. رسالة ماجستير غير منشورة، الجامعة المستنصرية، العراق.

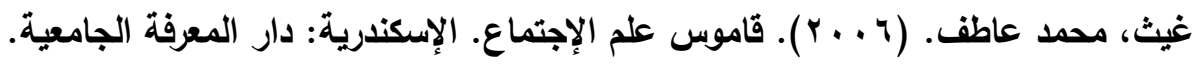

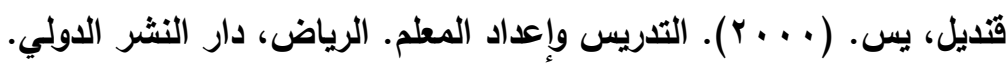

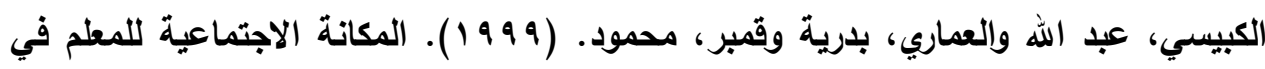

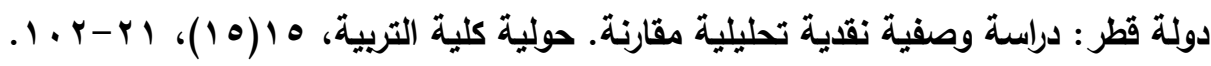

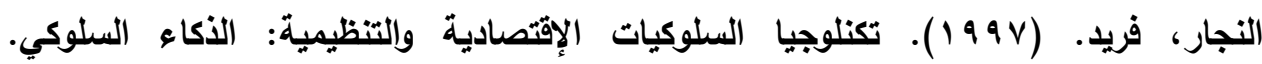
الإسكندرية: مؤسسة شباب الجامعة. 


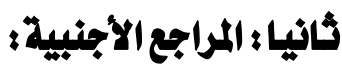

Cano-García, F. J., Padilla-Muñoz, E. M., \& Carrasco-Ortiz, M. Á. (2005). Personality and contextual variables in teacher burnout. Personality and Individual differences, 38(4), 929-940.

Clipa, O., \& Boghean, A. (2015). Stress factors and solutions for the phenomenon of burnout of preschool teachers. Procedia-social and behavioral sciences, 180, 907-915.

Dolton, Marcenaro, De-Vries, \& She. (2018). Global Teacher Status Index. Varkey Foundation: University Of Sussex.

Dubois, D., \& Nailya, O. (2015). Social Hierarchy, Social Status, and Status Consumption, in The Cambridge Handbook of Consumer Psychology, Michael I. Norton, Derek D. Rucker, and Cait Lamberton, eds. Cambridge, UK: Cambridge University Press, 332-367.

Hall, D., \& Langton, B. (2006). Perceptions of the status of teachers. Wellington, New Zealand: Ministry of Education.

Hardy, C. L., \& Van Vugt, M. (2006). Nice guys finish first: The competitive altruism hypothesis. Personality and Social Psychology Bulletin, 32(10), 1402-1413.

Hargreaves, L. (2009). The status and prestige of teachers and teaching. In International handbook of research on teachers and teaching (pp. 217-229). Springer, Boston, MA.

Kraus, M. W., Piff, P. K., Mendoza-Denton, R., Rheinschmidt, M. L., \& Keltner, D. (2012). Social class, solipsism, and contextualism: how the rich are different from the poor. Psychological review, 119(3), 546.

Linton, R. (1936). The study of man: An introduction. New York: D. Appleton-Century Co.

Opondo, R. (2002). A Study of The Diminishing Prestige Profession in Kenya: A Case Study of Nairobi Province, Unpublished Postgraduate Diploma, University of Nairobi, Kenya.

Sandilos, L. E., Goble, P., Rimm-Kaufman, S. E., \& Pianta, R. C. (2018). Does professional development reduce the influence of teacher stress on teacher-child interactions in pre-kindergarten classrooms?. Early Childhood Research Quarterly, 42(1), 280-290.

Verhoeven, J. C., Aelterman, A., Rots, I., \& Buvens, I. (2006). Public perceptions of teachers' status in Flanders. Teachers and Teaching: theory and practice, 12(4), 479-500. 